\title{
A review on impedimetric immunosensors for pathogen and biomarker detection
}

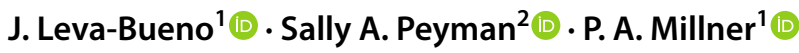

Received: 2 August 2019 / Accepted: 16 March 2020 / Published online: 3 April 2020

(c) The Author(s) 2020

\begin{abstract}
Since the discovery of antibiotics in the first quarter of the twentieth century, their use has been the principal approach to treat bacterial infection. Modernized medicine such as cancer therapy, organ transplantation or advanced major surgeries require effective antibiotics to manage bacterial infections. However, the irresponsible use of antibiotics along with the lack of development has led to the emergence of antimicrobial resistance which is considered a serious global threat due to the rise of multidrug-resistant bacteria (Wang et al. in Antibiotic resistance: a rundown of a global crisis, pp. 1645-1658, 2018). Currently employed diagnostics techniques are microscopy, colony counting, ELISA, PCR, RT-PCR, surface-enhanced Raman scattering and others. These techniques provide satisfactory selectivity and sensitivity (Joung et al. in Sens Actuators B Chem 161:824-831, 2012). Nevertheless, they demand specialized personnel and expensive and sophisticated machinery which can be labour-intensive and time-consuming, (Malvano et al. in Sensors (Switzerland) 18:1-11, 2018; Mantzila et al. in Anal Chem 80:1169-1175, 2008). To get around these problems, new technologies such as biosensing and lab-on-a-chip devices have emerged in the last two decades. Impedimetric immunosensors function by applying electrochemical impedance spectroscopy to a biosensor platform using antibodies or other affinity proteins such as Affimers (Tiede et al. in Elife 6(c):1-35, 2017) or other binding proteins (Weiss et al. in Electrochim Acta 50:4248-4256, 2005) as bioreceptors, which provide excellent sensitivity and selectivity. Pre-enrichment steps are not required and this allows miniaturization and lowcost. In this review different types of impedimetric immunosensors are reported according to the type of electrode and their base layer materials, either self-assembled monolayers or polymeric layers, composition and functionalization for different types of bacteria, viruses, fungi and disease biomarkers. Additionally, novel protein scaffolds, both antibody derived and non-antibody derived, used to specifically target the analyte are considered.
\end{abstract}

Keywords Biosensor $\cdot$ Electrochemical impedance spectroscopy (EIS) $\cdot$ Immunosensor $\cdot$ Bacteria $\cdot$ Virus $\cdot$ Biomarker

\section{Introduction}

Edited by: Volkhard A.J. Kempf.

P. A. Millner

P.A.Millner@leeds.ac.uk

J. Leva-Bueno

bsjlev@leeds.ac.uk

Sally A. Peyman

S.Peyman@leeds.ac.uk

1 School of Biomedical Sciences, Faculty of Biological Sciences, University of Leeds, Leeds LS2 9JT, England, UK

2 Molecular and Nanoscale Physics Group, Department of Physics and Astronomy, University of Leeds, Leeds LS2 9JS, England, UK
Several worldwide leading healthcare organizations such as the Centers for Disease Control and Prevention (CDC), Infectious Diseases Society of America and the WHO have asserted that antibiotic resistance is a global public threat. Evolution of pathogens along with human beings is a burden and resistance to antibiotics and antivirals are becoming widespread. Several studies reveal that around the 30-50\% of antibiotic treatments are inappropriate in the USA, where antibiotic-resistant hospital acquired infections (HAIs) are responsible for 99,000 deaths annually [1]. According to O'Neill's report within the UK, the problem of AMR by 2050 is estimated to put in risk 10 million human lives per year and will have spent a cumulative amount of 100 trillion USD [7]. Therefore, early detection of these microorganisms 
in humans or animals is essential to provide efficient and adequate treatment.

Currently employed diagnostics techniques are: microscopy, microbial culture, ELISA, PCR, RT-PCR, multipletube fermentation (MTF), SERS, and others. Microscopy is a very convenient technique to assess morphological features, but is less sensitive than microbial culture, which is particularly time-consuming, often more than $24 \mathrm{~h}$. Besides, microbial culture has low sensitivity and is relatively expensive [8]. Some immunoassay methods such as ELISA can specifically detect epitopes on bacterial surfaces. However, diagnostics based on ELISA are time-consuming, expensive, have a complex and narrow detection range and often show cross-reactivity [9]. PCR is appropriate for tiny samples and results in highly specific detection. However, PCR lacks reliability due to frequent false positive outcomes [10]. MTF consists of filtering a water sample, concentrating the bacterial cells and incubating them for later detection and quantification. Since the technique depends on bacterial growth, one test can last up to $96 \mathrm{~h}$ [11]. Finally, the SERS technique requires expensive and sophisticated laser equipment [12].

To overcome the preceding methodological difficulties, new technologies such as biosensing have emerged in the last few decades. This technology can detect and quantify biological analytes and combine high sensitivity and specificity with fast response times, portability, low-cost, and ease-of-use.

\section{Biosensors}

A biosensor [13] is defined as a compact analytical device that detects and quantifies a target analyte and consists of three elements: a biological receptor (DNA, antibodies, enzymes, cells) which specifically detect the target molecule; a transducer, which interprets the biological recognition event and translates it into a quantifiable signal; and a signal processing display. The rise of biosensors is due to the limitations that current techniques present such as high costs, requirement for qualified personnel and long response time. All of these complications are incompatible with earlystage rapid diagnosis (Fig. 1).

The first biosensor [14] dates back to 1962. An electrochemical biosensor was developed to measure glucose levels in blood. The enzyme glucose oxidase (GOx) catalyses the oxidation of the glucose, and the biosensor monitored its consumption through the change in the current at the working electrode. Since then, electrochemical biosensors have drawn the attention of several research areas due to their easy manipulation, great sensitivity and possibility for miniaturisation.

Biosensors for medical application are designed to detect and quantify biomedical analytes. Pathogens found in different bio-fluids such as saliva, urine and blood can be detected $[15,16]$. Nowadays, implantable biosensors have been already developed and are in use in some patients, for instance for a constant monitoring of glucose [17].

Biosensors can be classified either by their bioreceptor element or by the transduction mechanism. Where antibodies are used as bioreceptors they are called immunosensors. Antibodies are one of the most important bioreceptors to target specific analytes, taking advantage of the highly specific non-covalent interaction between antibodies and antigen [18]. Classifying by the type of transducer, the main categories are: optical, mechanical and electrochemical [19]. This last category, electrochemical, can be subdivided in to amperometric, potentiometric, conductometric and impedimetric [20].

\section{Optical biosensors}

Optical biosensors are based on the measurement of absorbance, reflectance, or fluorescence emission in the UV, visible, or near-infrared (NIR) [21]. The advantages of optical biosensors are mainly due to their high sensitivity, ability to monitor in real-time and the possibility of being label-free. The most utilized label-free transduction method is surface plasmon resonance (SPR).

SPR is a charge-density oscillation that occurs in the interface of the metal and the dielectric. In SPR, a plasmon wave is measured over a metal surface, and works by applying a light through the biological sample, causing a change in the refractive index, which is used to monitor the binding [22]. The commercialization of SPR is already well established. However, optical method can also suffer the disadvantage of interference by coloured analytes and many biofluids, for instance blood and urine, which show significant colour. Besides, SPR as well as many other optical methods requires sophisticated and expensive machinery [23, 24].

\section{Mechanical biosensors}

Mechanical biosensors detect changes in the properties of the surface upon a biological binding event. The sensor records surface stress or oscillation frequency due to mass deposition. Different type of mechanical biosensors are: surface-stress mechanical biosensors, that measures the change in deflection of the cantilever when a biomolecule binds to the surface. A laser beam is used to obtain the position of cantilever deflection; dynamic-mode mechanical biosensors, in which the device oscillates at a fixed resonance frequency, that changes upon biomolecule binding. Other types of biosensors are quartz crystal microbalance (QCM) and whispering-gallery microgravity (WGM). Although these techniques are robust, as they monitor surface mass 
Fig. 1 Schematics of biosensor platforms: general overview of biosensors in which different types of biorecognition elements and transduction mechanisms are shown and a signal processor. Some vectors are reproduced from CSIRO ScienceImage

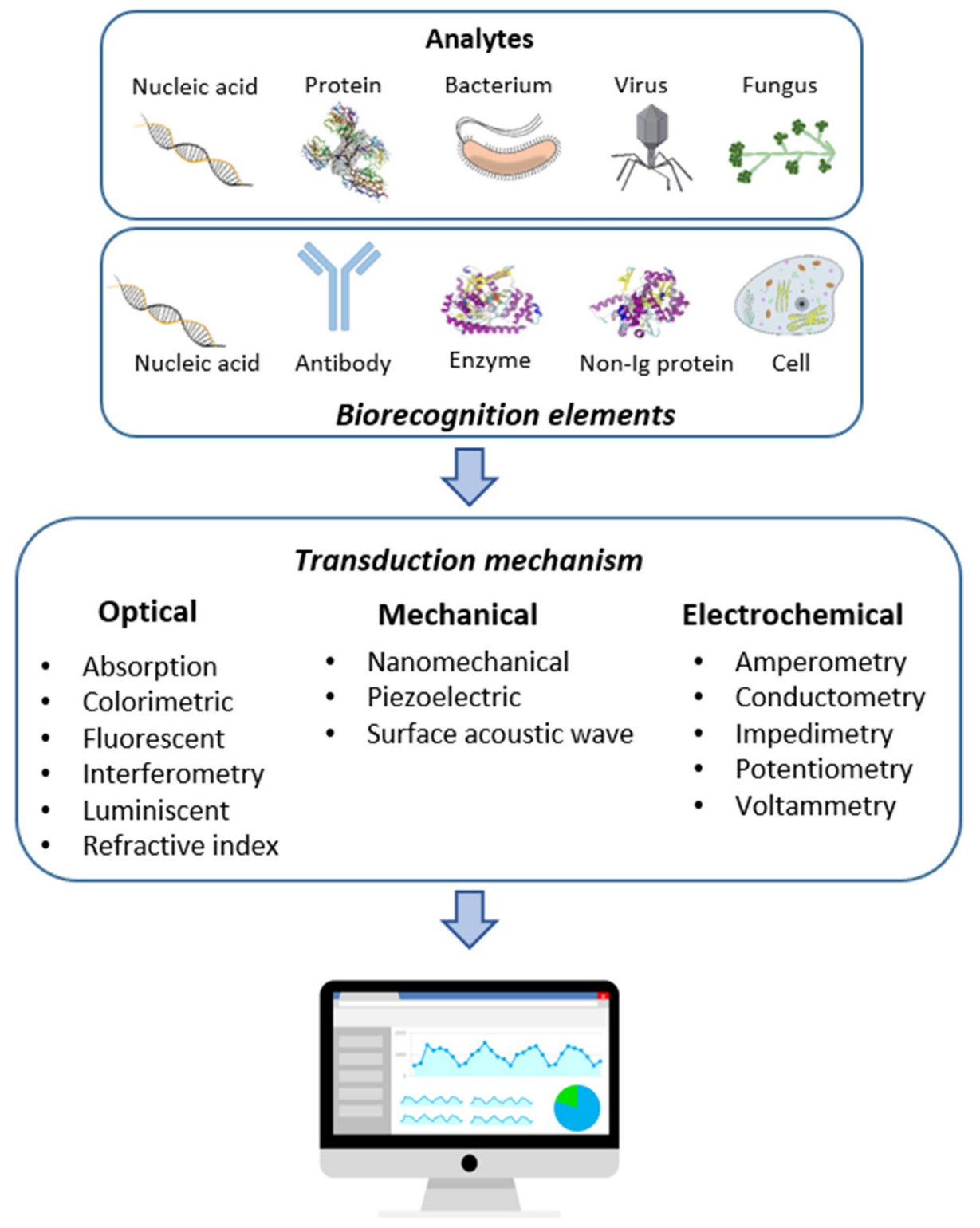

they are less sensitive to small molecules and non-specific deposition can be an issue [25].

\section{Electrochemical biosensors}

Electrochemistry is the branch of the chemistry that interrelates electrical and chemical reactivity [26]. Electrochemical transduction is one of the most abundant modes nowadays due to its rapid response time, user-friendly application, lowcost production and the possibility of miniaturizing the system. The basis of an electrochemical biosensor is to measure the changes that take place in the proximity of the electrode surface. There, electrons flow between the electrode surface and electrolytes in solution. The changes at the electrode surface are monitored through parameters such as electrolyte resistance, charge transfer at the electrode surface or mass transfer from the bulk solution to the electrode surface. For electrochemical biosensors, transduction can be subdivided in the following: potentiometric, amperometric and impedimetric [27].

\section{Potentiometric sensors}

Potentiometric biosensors [28] measures the potential at the working electrode, at zero current, with respect to the reference electrode. This measurement takes place under equilibrium conditions, when no current is flowing through the electrochemical cell. This technique is used to assess ion concentrations across the electrode surface. These biosensors combine biorecognition elements, mainly enzymes, with a transducer that measures the uptake or release of ions that occurs during the enzyme's action on its target. Ions such as $\mathrm{Na}^{+}, \mathrm{K}^{+}$, 
$\mathrm{Ca}^{2+}, \mathrm{H}^{+}$or $\mathrm{NH}_{4}^{+}$can all be measured, but typically are $\mathrm{H}^{+}$ or $\mathrm{NH}_{4}{ }^{+}$. Many potentiometric sensors are essentially modified $\mathrm{pH}$ electrodes [29]. The relationship between the free ion concentration and the potential is established by the Nernst equation (Eq. 1) and of course the stoichiometry between ion and target substrate enables calibration.

$E_{\text {cell }}=E_{\text {cell }}^{0}-\frac{R T}{n F} \ln Q$,

where $E_{\text {cell }}$ is the cell potential, $E_{\text {cell }}^{0}$ is the standard cell potential, $R$ is the universal gas constant, $T$ the temperature, $n$ is the charge number of electrode reaction, $F$ is the Faraday constant and $Q$ is the ratio of ion concentrations between the anode and the cathode.

In the case of voltammetric biosensors, the current is monitored as a result of the application of a varied potential. The three most known voltammetry techniques are potential step, linear sweep, and cyclic voltammetry (CV). CV is also useful in biosensor fabrication at the step of polymer-layer deposition, known as electropolymerisation [28, 30].

\section{Amperometric}

Typically, an amperometric biosensor measures the current at a constant potential [31]. The first practical biosensor was the glucose biosensor, which measured the depletion of oxygen and the change in current by the enzyme catalysed reaction of glucose oxidase (GOx) (Eq. 2) [14]. This biosensor was the first of what is called the first generation glucose biosensors, which are characterized for the employment of oxygen as a cosubstrate and the generation and detection of hydrogen peroxide (Eq. 3). The first generation was quickly superseded by replacing the need for oxygen by an electron mediator, such as ferrocene or potassium ferricyanide, which acts to reoxidise the lavin cofactor, leading to the second generation of glucose biosensors. Subsequently, the reduced mediator is oxidized at the electrode surface such in Eqs. 4, (5) and (6) [32]. Later improvements consisted of developing biosensors in which the electron transfer was carried out without the use of electron mediators. Instead, there was a direct exchange of electrons between the enzyme and the electrode. This is called third generation glucose biosensors. However, recent improvements and continuous glucose monitoring are being achieved by non-enzymatic glucose biosensors. These biosensors are considered the fourth generation glucose biosensors and are characterized for using a catalytic electrode for glucose oxidation. These electrodes are modified by electrodeposition, etching or electrochemical anodization [33].

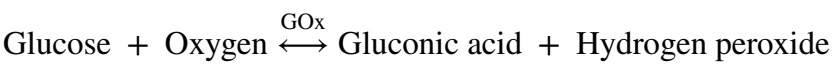

$\mathrm{H}_{2} \mathrm{O}_{2} \rightarrow \mathrm{O}_{2}+2 \mathrm{H}^{+}+2 \mathrm{e}^{-}$
Glucose $+\mathrm{GOx}_{(\mathrm{ox})} \rightarrow$ Gluconic acid $+\mathrm{GOx}_{(\mathrm{red})}$

$\mathrm{GOx}_{(\mathrm{red})}+2 \mathrm{M}_{(\mathrm{ox})} \rightarrow \mathrm{GOx}_{(\mathrm{ox})}+2 \mathrm{M}_{(\mathrm{red})}+2 \mathrm{H}^{+}$

$2 \mathrm{M}_{(\mathrm{red})} \rightarrow 2 \mathrm{M}_{(\mathrm{ox})}+2 \mathrm{e}^{-}$

Generally, in amperometric biosensors label-free is practically not possible and often an oxidoreductase enzyme catalyses the biochemical reaction, which turns into a change in current across the electrode surface, proportional to analyte concentration. These biosensors allow rapid responses and high sensitivity. However, their use are limited to analytes of which there are specific enzymes to catalyse the redox reaction. Faraday's Law (Eq. 7) can determine the relationship:

$I=n \cdot F \cdot A \cdot J$,

where $I$ is the current, $n$ the number of electrons transferred to the electrode, $F$ the Faraday constant, $A$ the area of the electrode and $J$ is the Flux coefficient.

Amperometric biosensors show better sensitivity than potentiometric biosensors. Nevertheless, these systems require enzymes to oxidise or reduce a specific analyte [34], which is a limitation on their use. Commercial amperometric biosensors determine the presence and concentration of glucose in animals and microbial cultures [35], lactose and other metabolites [36] and some lipids such as cholesterol [37].

\section{Impedimetric}

Impedance is basically the opposition to the current flow in an electrical circuit. The difference between common resistance and impedance is that resistance obeys Ohm's law and occurs in direct current (DC) circuits, where there is no gap between the voltage applied and the current. Impedance, however, occurs in full alternating current (AC) circuits, where there is a gap in the voltage-current phase angle due to appearance of capacitive and inductive effects. In the case of impedimetric biosensors, the impedance consists of a resistive and a capacitive part as a result of a complex interaction with a small amplitude voltage signal as a function of frequency [38, 39].

Unlike amperometric and potentiometric systems, impedance biosensors are label free and do not depend on any specific enzyme for the analyte detection. Instead, impedimetric biosensors rely on a unique bioreceptor which specifically binds to the analyte such as DNA [40], antibodies [41, 42] aptamers [43] and various synthetic affinity proteins such as Affimers [5, 44]. 


\section{Brief description of electrochemical impedance spectroscopy (EIS)}

\section{Electrochemistry at electrode surface}

When EIS is used on a biosensor, several parameters are obtained. Bulk impedance $(Z)$ can be separated into real and imaginary component, which are the resistive $\left(Z^{\prime}\right)$ and the capacitive $\left(-Z^{\prime \prime}\right)$ parts, respectively (Fig. 2). The resistive part is originated by the electrode surface through the opposition to the current flow. The capacitive part measures the storage of charge of the system when a voltage is applied. At the electrode-solution interface, there are two ways in which electricity can flow through the electrode: when the electrons are transferred to the electrodes by means of redox reactions it is called a Faradaic process and behaves according to Faraday's law. When no charge is transferred to the electrode surface, however, electricity can flow through since the system behave as a capacitor, it is called a nonFaradaic process $[45,46]$.

The basis of EIS consists of applying a low amplitude voltage sine wave to an electrochemical system over a range of frequencies. As a result, the current and its phase angle is obtained. The impedance is the ratio between the applied voltage and the current (Eq. 8) and indicates the opposition of an electrical circuit to the flow of electrons in the AC circuit. Impedance-based biosensors culminate with a bioreceptor-analyte interaction which causes modifications to the electrical field due to a change in the capacitance and electron transfer resistance at the working electrode surface [39].

$Z(j \omega)=\frac{V(j \omega)}{I(j \omega)}$,

where $Z$ is the impedance, $V$ is the voltage, $I$ is the current, $j$ is the imaginary component and $\omega$ is the frequency.

When the phase angle between the voltage and intensity is equal to zero, as in a pure metal surface, the impedance and resistance become the same. Nevertheless, in the majority of real electrical circuits the angle is different from zero as a consequence of capacitive and/or inductive effects.

To assess the impedance of an electrochemical system in Faradaic biosensors, the modified surface of the biosensor electrode is immersed in a solution containing an electron mediator. The most commonly used redox pairs include $\left[\mathrm{Fe}\left(\mathrm{CN}_{6}\right)\right]^{3-/ 4-}$ (ferricyanide/ferrocyanide), $\left[\mathrm{Ru}\left(\mathrm{NH}_{3}\right)_{6}\right]^{3+/ 2+}$ hexaammineruthenium (II/III) and ferrocene $\left(\mathrm{Fc}^{+} / \mathrm{Fc}\right)$. In non-Faradaic circuits, impedance is measured without a redox mediator [13].

Usually, a SAM or a polymer layer are used to cover the electrode surface. This coating provides a surface to immobilize the bioreceptors, increases their bio-stability and creates a dielectric between the surface and the media. Self-assembled monolayers (SAMs) require a molecularly flat surface, incompatible with the roughness presented by a gold screen-printed electrode (SPE) surface. Alternatively,
Fig. 2 Phasor diagram: a phasor diagram shows the change in phase angle $(\theta)$ and magnitude (IZI) when analyte binding occurs

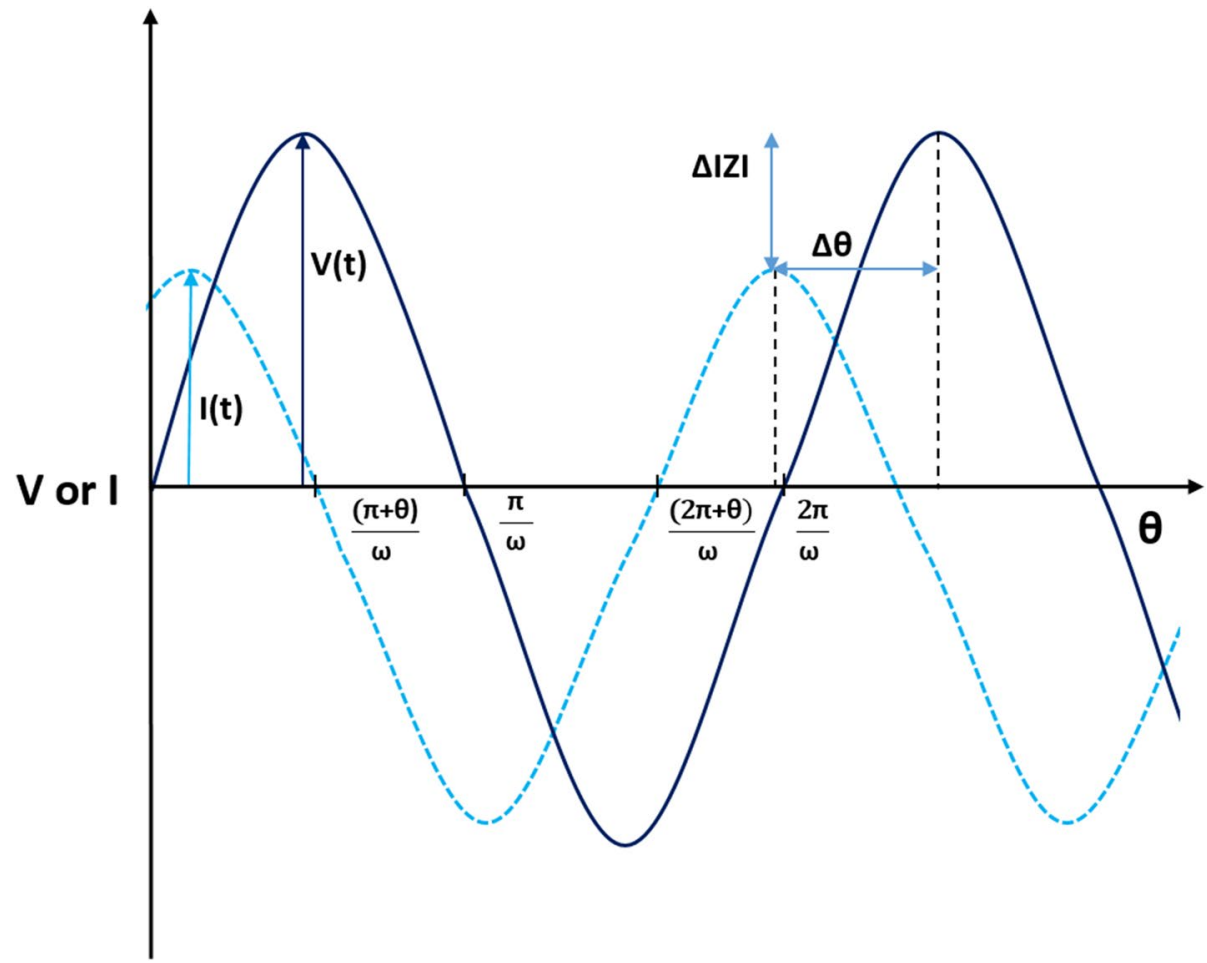


conducting and non-conducting polymers are typically electrodeposited onto metal surfaces. These polymers are good base layers since they can be electrodeposited onto rough surfaces and the thickness of the polymer itself can be controlled. Conducting polymers such as polyaniline (PANI) or polypyrrole (PPy) exhibit conductive or semi-conductive properties whereas non-conducting polymers like polytyramine (Ptyr) offer high resistivity and contribute to highly sensitive detection $[46,47]$.

\section{Equivalent circuit and data presentation}

Common formats for impedance data presentation are the Nyquist and Bode plots. In the Nyquist plot (Fig. 3a), the imaginary part of impedance $\left(-Z^{\prime \prime}\right)$, out of phase, is plotted against the real component $\left(Z^{\prime}\right)$, in phase, at each excitation frequency whereas the Bode plot, shows the logarithm of absolute impedance and phase shift $(\Theta)$ versus the log of excitation frequency. The Nyquist plots shows the relationship between real and imaginary components of impedance for a range of frequencies and are typically used to assess the resistive component of the system whereas Bode plots are used to study mainly the capacitive $[48,49]$. The Nyquist plot is explained in detail for the common use of data assessment in this project (Fig. 3a).

The behaviour of the system is different at high and low frequencies. At high frequencies, the signal is controlled by kinetic processes: electron mediator molecules change in charge direction before the redox reaction at the electrode surface takes place. This fact constitutes a limiting factor since it delays the charge transfer across the electrode. This limitation is known as solution resistance $\left(R_{\mathrm{s}}\right)$. At medium frequencies, there is barely resistance in the system. As a consequence, the changes originated in the system are due to capacitance, specifically from the double layer capacitance $\left(C_{\mathrm{dl}}\right)$ at the electrode surface. At low frequencies, charge
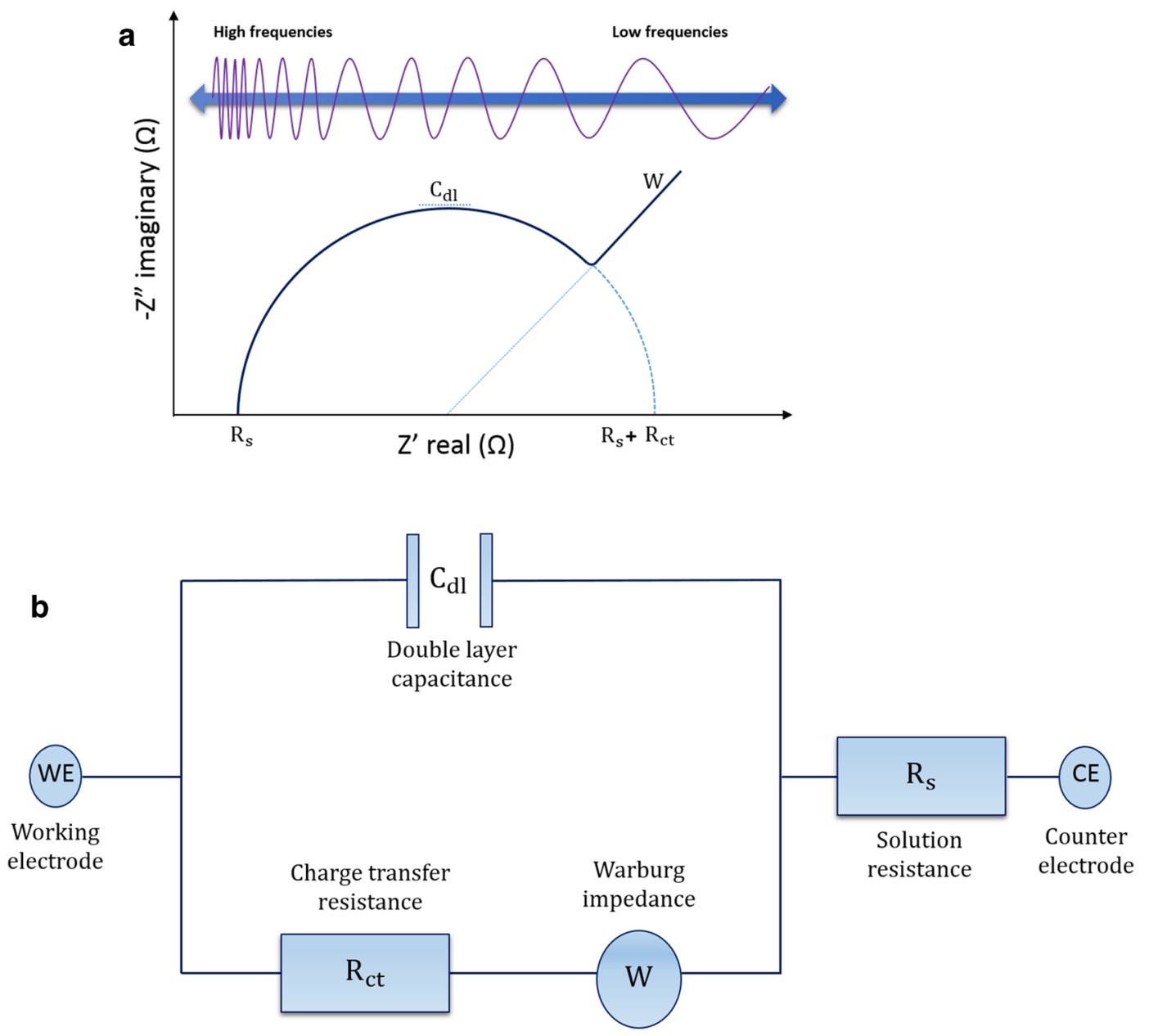

Fig. 3 General scheme of a Nyquist plot and its Randles' equivalent circuit: a Nyquist plot emerges from plotting the imaginary (capacitive) against real (resistive) components of impedance. Most relevant features are: resistance of the solution $R_{\mathrm{s}}$; charge transfer resistance
$R_{\mathrm{ct}}$; the maximum double-layer capacitance $C_{\mathrm{dl}}$ and the Warburg impedance $W$, which is only observed in Faradaic sensors and represents mass transfer diffusion effects. b Randles' equivalent circuit representing an electrical circuit modelling a Faradaic sensor 
transfer is only produced by the resistance offered from the biosensor construct, since the opposition found by the electron mediators is due to the surface components. This resistance is calculated through the charge transfer resistance $\left(R_{\mathrm{ct}}\right)$ [50]. In some occasions, at low frequencies, is seen Warburg impedance $(W)$, which is manifested as a linear tail at the end of the Nyquist arc. This phenomena occurs due to diffusional limitations of the systems, when it runs out of charge carriers [46]. The equivalent circuit for all these components is represented on a Randles' equivalent circuit (Fig. 3b) which models the behaviour of a typical Faradaic biosensor.

Generally, the tendency of the impedance value is to increase as the complexity of the functionalized electrode increases: electrons in solution face more obstacles when reaching the electrode surface and thus, more resistance is observed (Fig. 4). However, a decrease in impedance can occur upon analyte binding, since analyte binding can distort the polymer layer and make electron mediator access easier [51].

In Faradaic measurements, the main aim is to calculate the charge transfer resistance and the current flowing through the biosensor surface. In contrast, in non-Faradaic measurements, a voltage at low frequencies is applied and the current flows through the biosensor after accumulating the capacitive components of the surface. In general terms, Nyquist plots are typically used for resistive systems whereas Bode plots are used for capacitive [48, 49].

In this review the progress of impedimetric immunosensors field in the last two decades is discussed, according to a wide range of pathogens and biomarkers. The characteristics of a biosensor are the working electrode, target element, immobilization step, limit of detection (LOD), detection time and sample volume. Previous reviews about biosensors classify them either by type of bioreceptor or by type of transducer. In this case, the bioreceptor consists of an antibody and the transducer component is an impedance electrode. Thus, the classification in this review is organised by type of analyte: bacteria, virus and fungi, biomarkers and a final section of new protein receptors.

\section{Immunosensors for pathogen detection}

\section{Escherichia coli (E. coli)}

Escherichia coli is a gram-negative bacteria primarily found in the intestines of mammal and birds. Common strains are not harmful even at high concentrations. However, a few $E$. coli strains can cause illness, for instance strain O157:H7 which produces a haemorrhagic toxin and causes haemorrhagic colitis [52]. Impedimetric immunosensor platforms for $E$. coli have been the object of many studies due to its easy manipulation in the laboratory and it being a surrogate organism for sensing faecal pollution of water [53].

One of the first relevant cases of an E. coli impedance immunosensor [54] employed gold interdigitated array microelectrodes (IDAMs) and were modified and inserted in a microfluidic device [55] for E. coli O157:H7 detection. The system was capable of detecting concentrations as low as $1.2 \times 103 \mathrm{CFU} / \mathrm{mL}$ from ground beef samples and $1.6 \times 102 \mathrm{CFU} / \mathrm{mL}$ from pure culture in only $35 \mathrm{~min}$ using $100 \mu \mathrm{L}$ of sample. Specific antibodies against $E$. coli were conjugated to magnetic nanoparticles via biotin-streptavidin coupling, forming magnetic nanoparticle-antibody

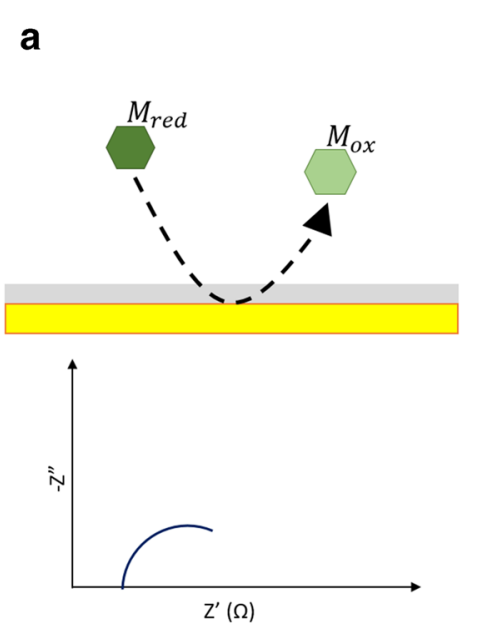

Fig. 4 General scheme of impedance for each step of biosensor construction. Impedance increases as the deposition over the surface electrode increases. Deposition of material onto biosensor surface normally causes an increase in both resistance and capacitance, which
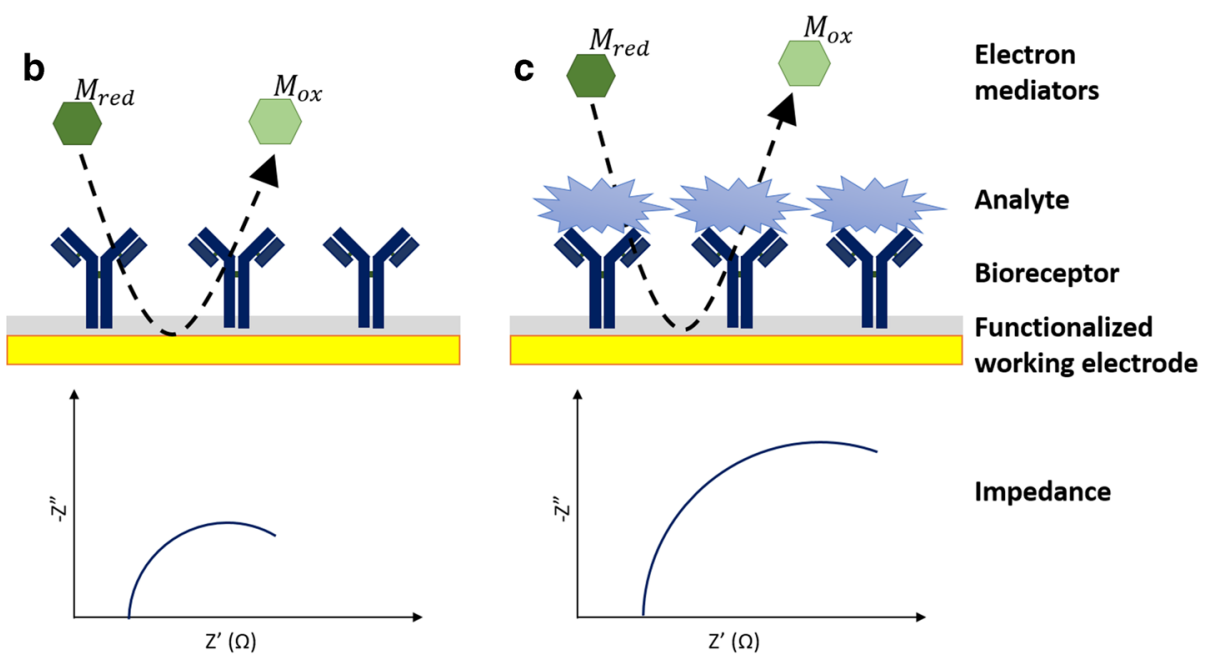

impedes the transfer of electrons between the solution-based mediators and the electrode surface. Therefore, impedance increases from (a), bare electrode when (b), bioreceptors are immobilized and (c), increases upon analyte binding 
conjugates (MNAC). These conjugates captured bacteria and concentrated them after applying a magnetic field. Eventually, the sample was placed into the microfluidic device for impedimetric assessment. Unlike macro-sized electrodes, which generally consists of a metal bar immersed into a solution, the use of IDAMs in impedance immunosensors [56] presents several advantages. For instance, lower detection limit, higher signal/noise ratio, shorter detection time and lower sample volume. The IDAMs' design is based on a pair of parallel microband array electrodes that mesh into each other forming a set of interdigitated electrode fingers. Frequently dimensions used for IDAMs are $0.1-0.2 \mu \mathrm{m}$ high for each electrode finger, $1-20 \mathrm{~mm}$ in length with an inter-electrode space of 1-20 $\mu \mathrm{m}$. Gold is the most prevalent material for IDAM fabrication. However, the use of indium tin oxide (ITO), Pt, Ti, Pd or Rh is also mentioned [20, 55].

Escherichia coli $\mathrm{O} 157: \mathrm{H} 7$ detection in river water [57] was achieved by covering gold electrodes with a mercaptoacetic acid (MACA) SAM. Subsequently, the construct was treated with $N$-ethyl- $N$-(dimethylaminopropyl)-carbodiimide (EDC) and $N$-hydroxysuccinimide (NHS) to catalyse the creation of a peptide bond with antibodies. The co-addition of NHS and EDC causes the replacement of the terminal carboxylic group of MACA by an NHS ester which is then subjected to nucleophilic attack by an amine group. An LOD of $1 \times 10^{3} \mathrm{CFU} / \mathrm{mL}$ analysing a small sample volume of $20 \mu \mathrm{L}$ was achieved in $1 \mathrm{~h}$, which compared to $100 \mu \mathrm{L}$ sample [54] decreases the volume despite longer detection time but was still acceptable. Usually, SAMs forms an insulation barrier between the electrode and the analyte solution, thus behaving as a dielectric. This dielectric barrier is used to investigate electron transfer [58].

A microfluidic biosensor platform was describe for $E$. coli and Staphylococcus aureus (S. aureus) detection [59]. On this occasion, antibodies were attached onto a modified alumina nanoporous membrane with self-assembled (3-glycidoxypropyl) trimethoxysilane (GPMS) SAM. The use of nanoporous alumina membrane in impedimetric immunosensing is due to the increase in the electron transfer through the electrode-solution interface caused by its high pore density, successful biocompatibility and expansion of surface area. Moreover, these membranes are extraordinarily long-lasting and the pore size can be regulated without difficulty [60]. Both type of bacteria were detected in $2 \mathrm{~h}$ and at an LOD of $10^{2} \mathrm{CFU} / \mathrm{mL}$ was achieved. Alumina nanoporous membrane was also reported [61] but adding a modification with hyaluronic acid (HA) (Fig. 5). HA is a hydrophilic non-sulphated glycosaminoglycan which is used in immunosensor construction to improve the signal/ noise ratio by decreasing non-specific background signals. It also enhances antibody immobilization due to its carboxyl groups. The biosensor platform could detect concentrations of $E$. coli as low as $83.7 \mathrm{CFU} / \mathrm{mL}$ in milk samples.
Therefore, the introduction of HA improved the previous sensitivity obtained in [59]. In other cases of biosensor fabrication using HA [2], introducing a conducting polyaniline (PANI) film surface prior to antibody immobilization [62] led to a low LOD of $2 \mathrm{CFU} / \mathrm{mL}$ [27] being reported.

Reduced graphene oxide paper (rGOP) electrode modified with gold nanoparticles (AuNPs) was used as a novel system for E. coli $\mathrm{O} 157: \mathrm{H} 7$ detection in cucumber and ground beef samples [53]. The AuNPs were electrodeposited onto the graphene paper and antibodies were linked to them via biotin-streptavidin coupling. Graphene, in addition to its advantages of biocompatibility, rapid electron transfer and large specific area surface, is characterised for its high flexibility and thus their great importance in impedimetric immunosensors. Incorporation of AuNPs in the biosensors construction was carried out due to their well-known functionalization chemistry and electrochemical properties [63]. AuNPs create an appropriate microenvironment for the stabilization and immobilization of biomolecules as well as ease the electron transfer between the bulk material on the electrode and the electrode itself [64]. Some impedimetric immunosensors require an amplification step in order to increase sensitivity, for instance by employing AuNPs [65] or the lectin wheat germ agglutinin (WGA) (Fig. 6). In this case, screen-printed interdigitated microelectrodes (SPIMs) was used as a biosensor platform, covered with 3-dithiobis(sulfosuccinimidyl propionate) (DTSP), and further functionalized until depositing antibodies. Once the bacteria was tested, WGA served as a signal amplifier [66]. The biosensor functionalization can be followed in (Fig. 6a) scheme and each step monitored through impedance and show in Nyquist plot in (Fig. 6b). Different bacterial concentrations are plotted by $\%$ change in impedance in (Fig. 6c).

Magnetic nanobeads served as a substrate to be coated with antibodies [67]. These antibody-coated magnetic nanobeads are used for separating and transporting the bacteria from the initial culture into another platform for electrochemical measurement and for concentrating and precipitating the pathogen onto the electrode by placing a magnet under the electrode. Common materials for working electrodes are gold, silver, platinum and carbon. However, a biosensor platform was built over an (ITO) electrode [68] and showed successful results: an LOD of $1 \mathrm{CFU} / \mathrm{mL}$ in a $400 \mu \mathrm{L}$ PBS sample could be obtained in $45 \mathrm{~min}$. Similarly, a gold-tungsten microwire was used as a working electrode modified with polyethyleneimine (PEI) SAM for E. coli K12 detection [69]. One of the latest impedimetric immunosensor fabrication [3] tried 5 distinct manners of functionalizing the electrode surface with anti-E. coli onto a gold SPE and detected an LOD of $3 \mathrm{CFU} / \mathrm{mL}$ in $90 \mathrm{~min}$ for a $1 \mathrm{~mL}$ sample. Considering main important features such as LOD, detection time and sample volume, the biosensors using ITO electrode [68] and gold SPE [3] provide better sensitivity whereas 
Fig. 5 a Scheme of the impedimetric immunosensor constructed into a HA-coated alumina nanoporous for $E$. coli detection inserted into a microfluidic device. b A FESEM image showing bacteria captured over the nanoporous membrane. Scale bar is $1 \mu \mathrm{m}$. c the plot on the left shows a normalized impedance change (NIC) for different bacteria concentration and the plot on the right shows the validation experiments through negative control bacteria. Reprinted from [61], with permission from Elsevier

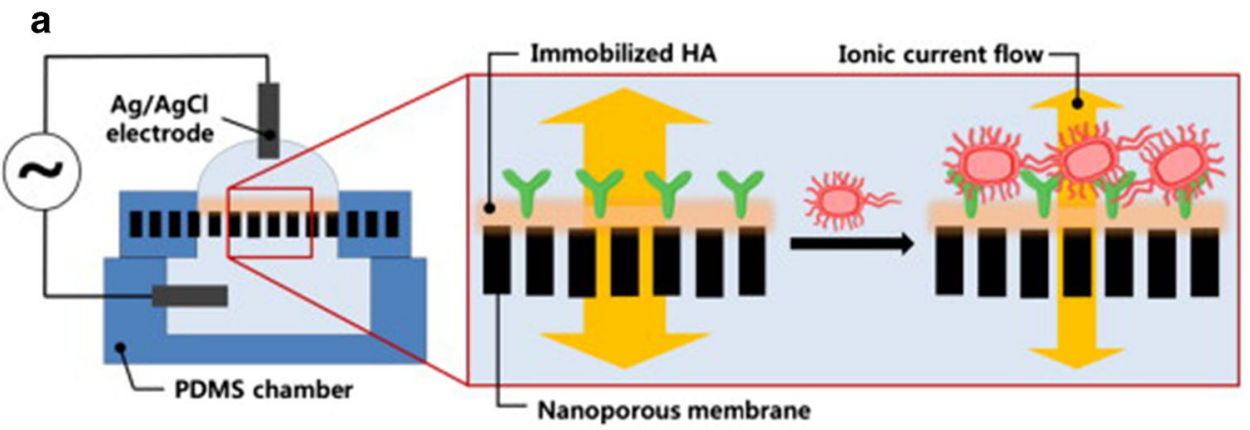

b

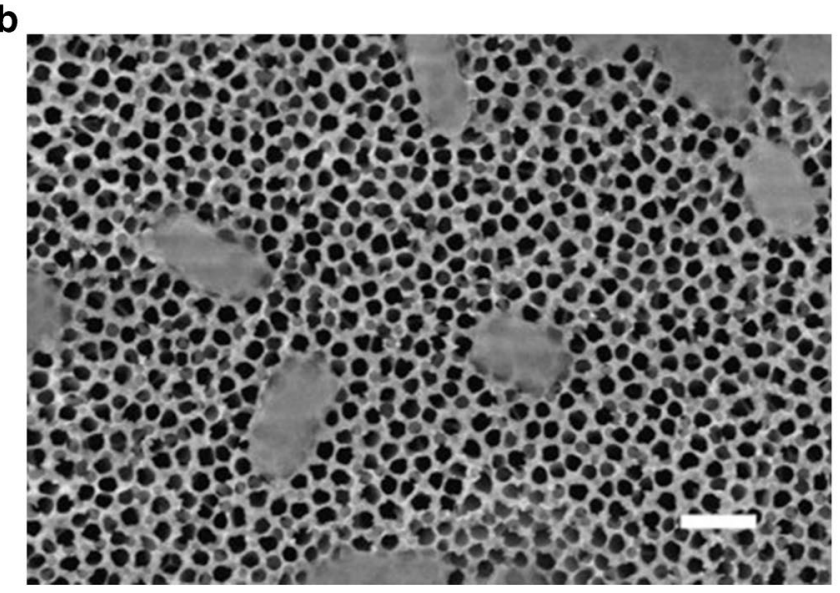

C

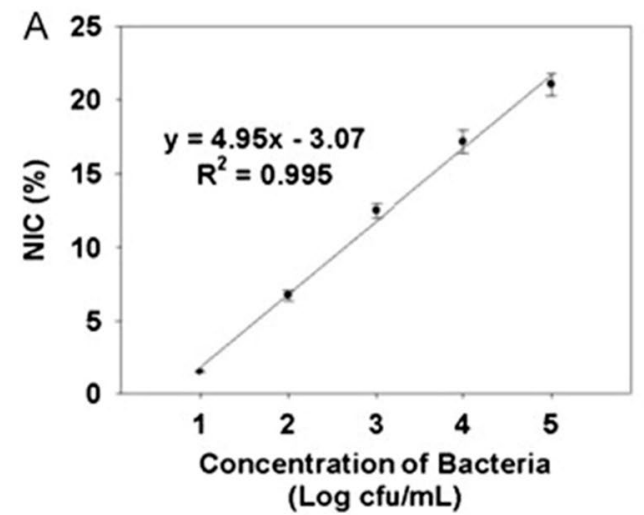

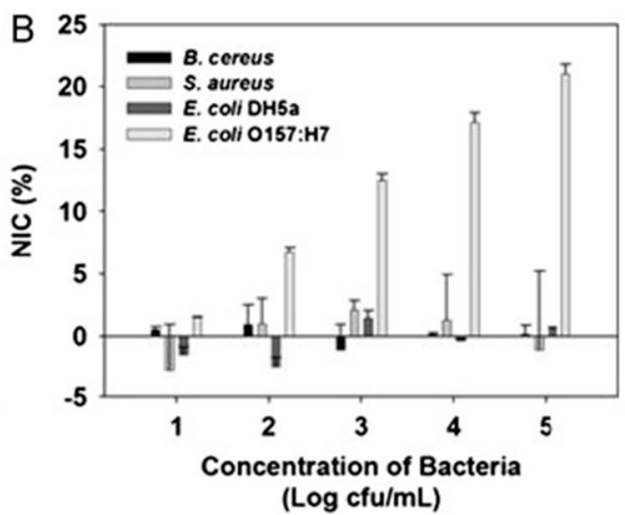

the biosensors using gold IDAM [54] and gold electrode with a MAA SAM [57] use considerably smaller sample volumes, thus less invasive towards the obtaining sample from patients. All four detection could be carried out in a relative short detection time, from 35 to $90 \mathrm{~min}$.

\section{Salmonella}

Salmonella is a gram-negative bacteria which belongs to the Enterobacteriaceae family. The most prevalent types of Salmonella which infect humans are Salmonella typhimurium (S. typhimurium) and Salmonella typhi (S. typhi). $S$. typhimurium is the less virulent and its common symptoms appear 12-72 $\mathrm{h}$ after infection. They include fever, diarrhoea, abdominal colic and headache. However, S. tiphi causes typhoid fever disease, causing around 200,000 deaths per year and a morbidity of approximately 20 million new cases per year [70].

An immunosensor for S. typhimurium evaluation in milk samples [71] was fabricated using a gold working electrode covered with a thiol-based SAM in which antibodies against Salmonella were attached via glutaraldehyde crosslinking. The immunosensor platform could attain an LOD of $10^{2} \mathrm{CFU} / \mathrm{mL}$ in a $2 \mathrm{~mL}$ PBS after $2 \mathrm{~h}$ whereas an LOD of $10^{2} \mathrm{CFU} / \mathrm{mL}$ was obtained after $10 \mathrm{~h}$ in a $2 \mathrm{~mL}$ milk sample. Similarly, antibodies were also attached to the SAM via glutaraldehyde [72]. One thousand $\left(10^{3}\right) \mathrm{CFU} / \mathrm{mL}$ in $1 \mathrm{~mL}$ of pathogen could be detected in only $20 \mathrm{~min}$, thus improving 
a

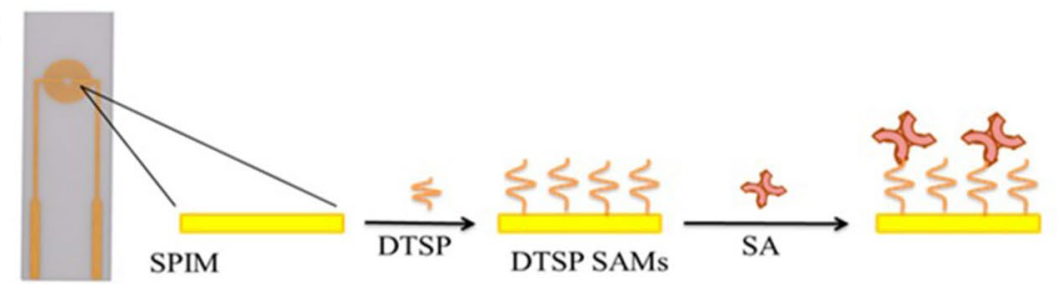

A
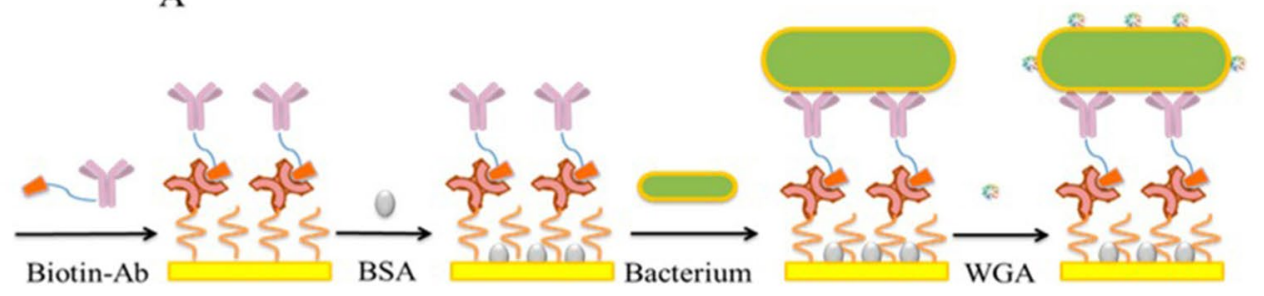

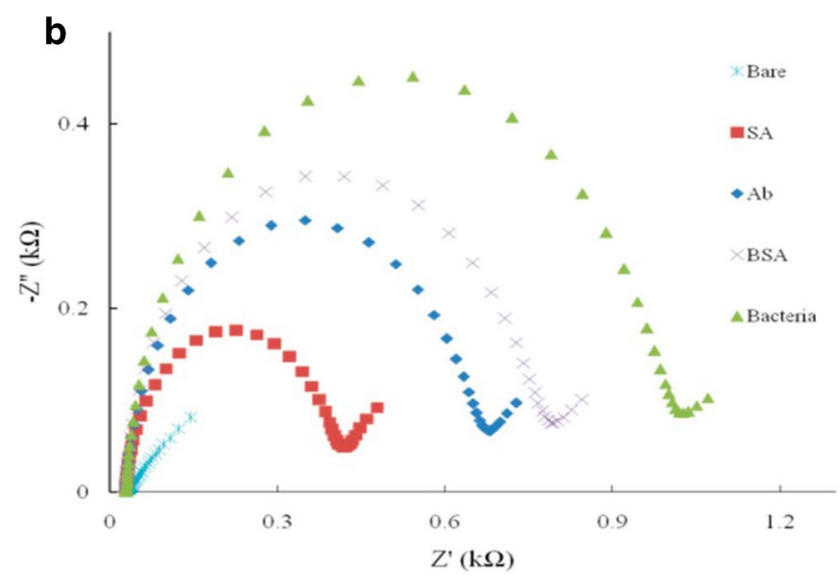

Fig. 6 a Scheme for layer-by-layer construction of the impedimetric detection immunosensor. b Nyquist plot of each step electrode functionalization. For bare electrode the impedance value is almost negligible. As the complexity of the electrode surface increases the impedance also does since the pathway of the electrons to get the surface

results published in [71]. Gold IDAMs were employed for immunosensor construction [73] using novel magnetic silica nanotubes (MSNTs) to capture bacteria through electrostatic interaction. The use of MSNTs is due to their multifunctional structure and for being less susceptible to self-aggregation under elevated levels of salt in the media. Another cases using a gold IDAM [74] was able to detect in $1 \mathrm{~h}$ an LOD of $10^{2} \mathrm{CFU} / \mathrm{mL}$ in only $50 \mu \mathrm{L}$ volume, thus improving previous sample volumes reported in [71, 72]. For S. typhi detection [75] AuNPs were coated with antibodies and an LOD of $10^{2} \mathrm{CFU} / \mathrm{mL}$ in $10 \mu \mathrm{L}$ sample could be achieved in $1 \mathrm{~h}$.

\section{Sulphate reducing bacteria (SRB)}

The electron transport chain of Desulforibrio caledoiensis, an SRB, possesses a sulphate as a terminal electron acceptor and thus, produces sulphide, which is known for being

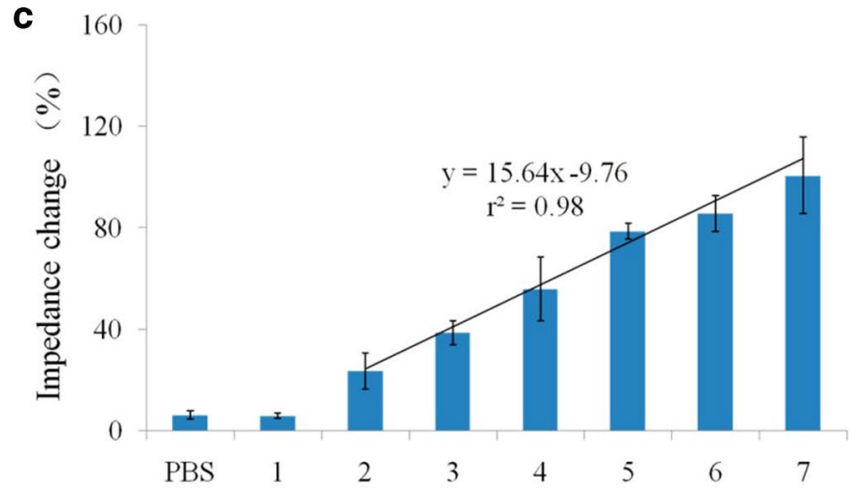

Concentration of bacteria $\left(\log \mathrm{cfu} \mathrm{mL}^{-1}\right)$

is more hindered. c Impedance change (\%) plotted against log (CFU/ $\mathrm{mL}$ ) of bacteria concentration. The increase in bacteria concentration creates a thicker platform, which turns an increase in the impedance value. Reproduced from [66]

a major problem for industries and the environment. One of the first impedimetric immunosensor for SRB detection immobilized the lectin-concanavalin A (ConA) for an agglutination assay [76]. The gold electrode was modified with a SAM onto which the lectin ConA was immobilized. Each lectin molecule presents four carbohydrate-combining sites. Therefore, when lectins react with cells they will also cause cross-linking and then precipitation [77]. A immunosensor for SRB [78] introduced the utilization of a Ni foam, covered with 11-mercaptoundecanoic acid (MPA), which worked as a platform for trapping bacteria. This system is depicted in Fig. 7. Further inclusion of reduced graphene sheets (RGS) in the SRB biosensor [79] was also reported. These 2D nanostructures are biocompatible, provide a redox catalyst and a low manufacturing cost [80]. A RGS-doped chitosan nanocomposite film biosensor platform could detect a range of bacteria at concentrations from $1.8 \times 10^{2}$ to $1.8 \times 10^{7} \mathrm{CFU} /$ $\mathrm{mL}$. In comparison to the work on SRB detection [76, 78], 

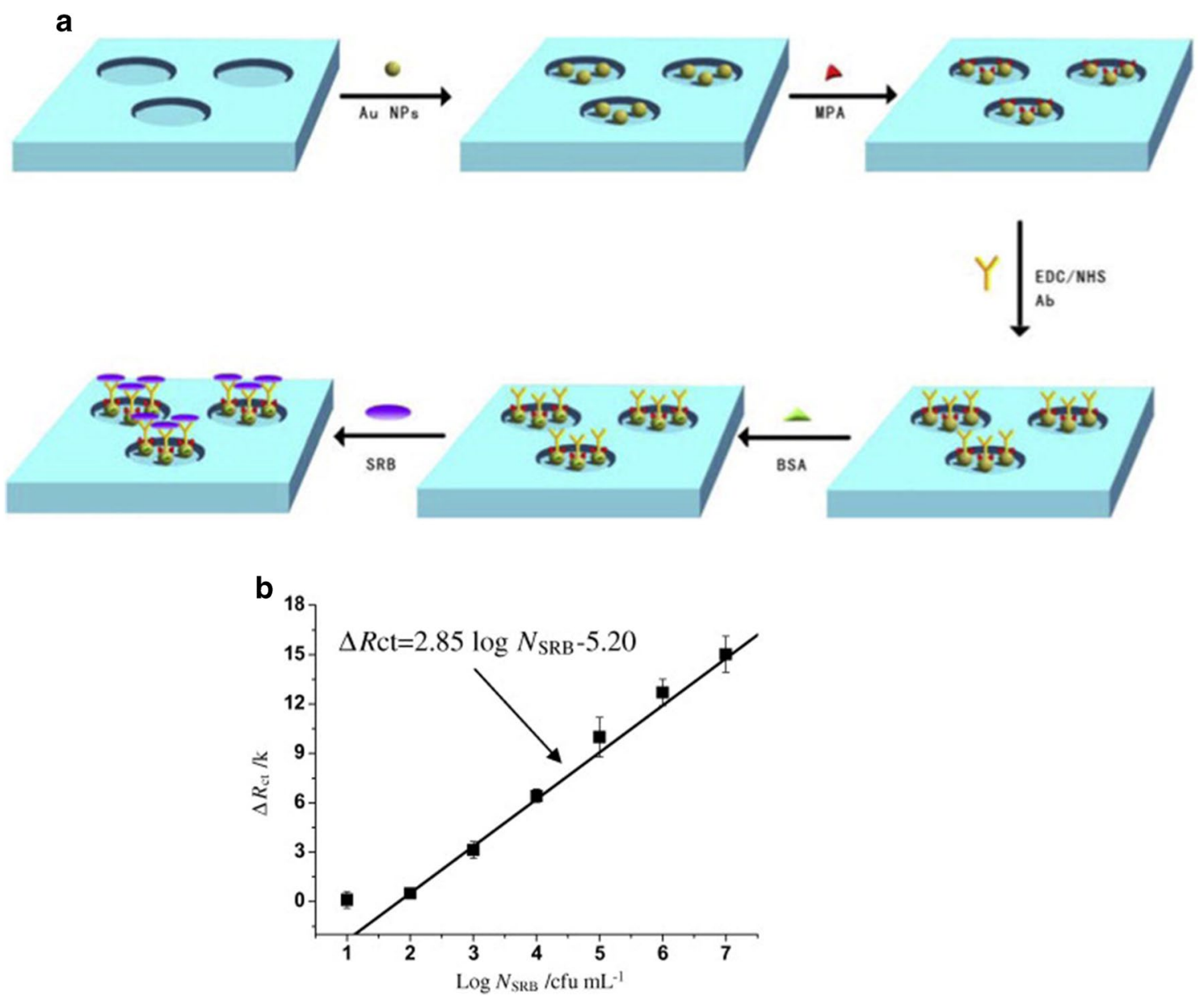

Fig. 7 a General scheme of the biosensor construction for SRB detection over 3D-foam Ni foam. b Change in $R_{\text {ct }}$ plot showing a calibration curve for different bacterial concentrations. Reprinted from [78], with permission from Elsevier

this RGS-based immunosensor obtained faster results and, even though the sensitivity was not improved, the sample amount could be as low as $10 \mu \mathrm{L}$.

\section{Listeria monocytogenes}

Listeria monocytogenes is a gram-positive bacteria whose infection takes place via contaminated food ingestion. Generally, the diseases caused by this bacteria includes febrile gastroenteritis, perinatal infection and systemic infections in which the central nervous system is affected. Hence, faster and cheaper methodologies such as impedimetric immunosensor have been researched [81].

An immunosensor [82] for Listeria monocytogenes employed a $\mathrm{TiO}_{2}$ nanowire bundle microelectrode. Pathogen detection was accomplished in $50 \mathrm{~min}$ for an LOD of $4.7 \times 10^{2} \mathrm{CFU} / \mathrm{mL}$ in $15 \mu \mathrm{L}$ sample. This clearly outperformed the common immunoassay detection and dot blot assay, with LODs of $10^{4} \mathrm{CFU} / \mathrm{mL}$ and $2.2 \times 10^{5} \mathrm{CFU} / \mathrm{mL}$ respectively. The use of a $\mathrm{TiO}_{2}$ nanowire is mainly due to its unique semi-conductive band gap not found in other nanowires, favourable biocompatibility and good chemical and photochemical stability, as well as easy fabrication [82]. Forward steps towards miniaturisation and low volume samples were also achieved [83] by inserting a biosensor into a micro fluidic device. Magnetic nanoparticles $30 \mathrm{~nm}$ diameter were coated with antibodies against the pathogenic bacteria via biotin-streptavidin coupling. The system could analyse bacteria in a 3-h immunoreaction for food samples (milk, ground beef and lettuce), achieving an LOD of $10^{4} \mathrm{CFU} / \mathrm{mL}$. Due to microfluidic chip use, the volume sample required was only $20 \mathrm{~nL}$, which justifies the limitation of sensitivity when using minimal sample volume. The main features of using a microfluidic device for biosensing include an increased ratio surface/volume and the insertion of small volumes in the order of nanoliters inside the microchannels, turning into a considerable reduction of the detection time and minimising the cost of reagents [83]. 


\section{Pseudomonas aeruginosa, Streptococcus pyogenes and Staphylococcus aureus}

Pseudomonas aeruginosa is a gram-negative bacteria commonly found in contaminated water. Infections by this pathogen in humans is manifested as urinary tract infections, respiratory system infections and systemic infections among others. An impedimetric immunosensor for this pathogen [84] was designed by immobilising polyclonal antibodies against $P$. aeruginosa over a screen-printed carbon electrode (SPCE). Streptococcus pyogenes is a gram-positive bacterium responsible of pharyngitis, scarlet fever (rash) impetigo, cellulitis, or erysipelas. An immunosensor was described [41] in which Dropsens gold SPEs were modified by depositing a polytyramine (Ptyr) layer. Subsequently biotin tagged antibodies were attached via biotin-NeutrAvidin. An LOD of $10^{2}$ cells were achieved for single shot incubation method with a sample volume of $10 \mu \mathrm{L}$ in only $30 \mathrm{~min}$ (Fig. 8). S. aureus is a gram-positive bacteria member of the Micrococcaceae family. Infections caused by this pathogen include diseases such as pneumonia, heart valve infections and bone infections which produces a considerable morbidity and mortality. An impedimetric immunosensor for stressed and resuscitated $S$. aureus assessment [85] was developed by modifying a gold electrode with an insulating 6-mercaptohexadecanoid acid SAM in which specific antibodies against $S$. aureus were attached for the further immunoreaction.

\section{Viral and fungal detection}

Avian Virus Influenza (IV) H5N1 is highly pathogenic and mainly occurs in birds. However, human infection by this virus is generally associated with several disease and death. A biosensor platform for IV H5N1 detection [86] immobilized polyclonal antibodies against IV H5N1 surface antigen HA (hemagglutinin) over a modified gold IDAM via protein A. An LOD of $10^{3} \mathrm{EID}_{50} / \mathrm{mL}\left(\mathrm{EID}_{50}: 50 \%\right.$ egg Infective Dose) and linear detection range from $10^{3}$ to $10^{7} \mathrm{CFU} /$ $\mathrm{mL}$ was achieved in $2 \mathrm{~h}$ in a $50 \mu \mathrm{L}$ sample. Protein A adsorbs easily onto the gold IDAM surface through electrostatic and hydrophobic interactions. Besides, this protein shows high affinity to the anti-H5N1 IgG Fc region, which facilitates antibody immobilization onto the electrode surface. Similarly, IV H5N1 detection in chicken swabs was achieved [38]. A gold IDAM was used as an electrode platform and was functionalised via protein $\mathrm{A}$ with monoclonal antibodies against IV H5N1. Concentrations from $2^{-1}$ to $2^{4} \mathrm{HAU} / 50 \mu \mathrm{L}$ (HAU: hemagglutination units) could be assessed in a $30 \mu \mathrm{L}$ sample after $45 \mathrm{~min}$.

Other impedimetric immunosensors include a regenerable biosensor for adenovirus type 5 (Ad5) detection [87], a biosensor for plum pox virus (PPV) [88] which affects plants from genus Prunus and a biosensor platform for the pathogen oomycete fungus Aphanomyces invadans [89], known to cause epizootic ulcerative syndrome (EUS).

\section{Biomarker detection}

\section{Biomarkers for cardiovascular disease (CVD)}

Cardiovascular diseases (CVD) is a major cause of death worldwide, estimated to be up to $30 \%$. Several disorders such as deep vein thrombosis (DVT), congenital heart disease, pulmonary embolism, cerebrovascular disease, coronary heart disease, rheumatic heart disease and peripheral artery disease are include in CVD. Some unmodifiable risk factors of suffering from a CVD are the gender, age, ethnicity and family history whereas among modifiable risk factors can be found in tobacco use, sedentary lifestyle,
Fig. 8 On the left, there is the general scheme of immunosensor against Streptococcus pyogenes construction layer-by layer over a DropSens gold SPE (CX2223AT). On the top right, a fluorescence imaging of bound $S$. pyogenes on the sensor surface. On the bottom right, there is a \% change in impedance plot upon the addition of different bacteria concentration, from $10^{4}$ to $10^{8}$ cells $/ \mathrm{mL}$. Reproduced from [41], with permission of ACS
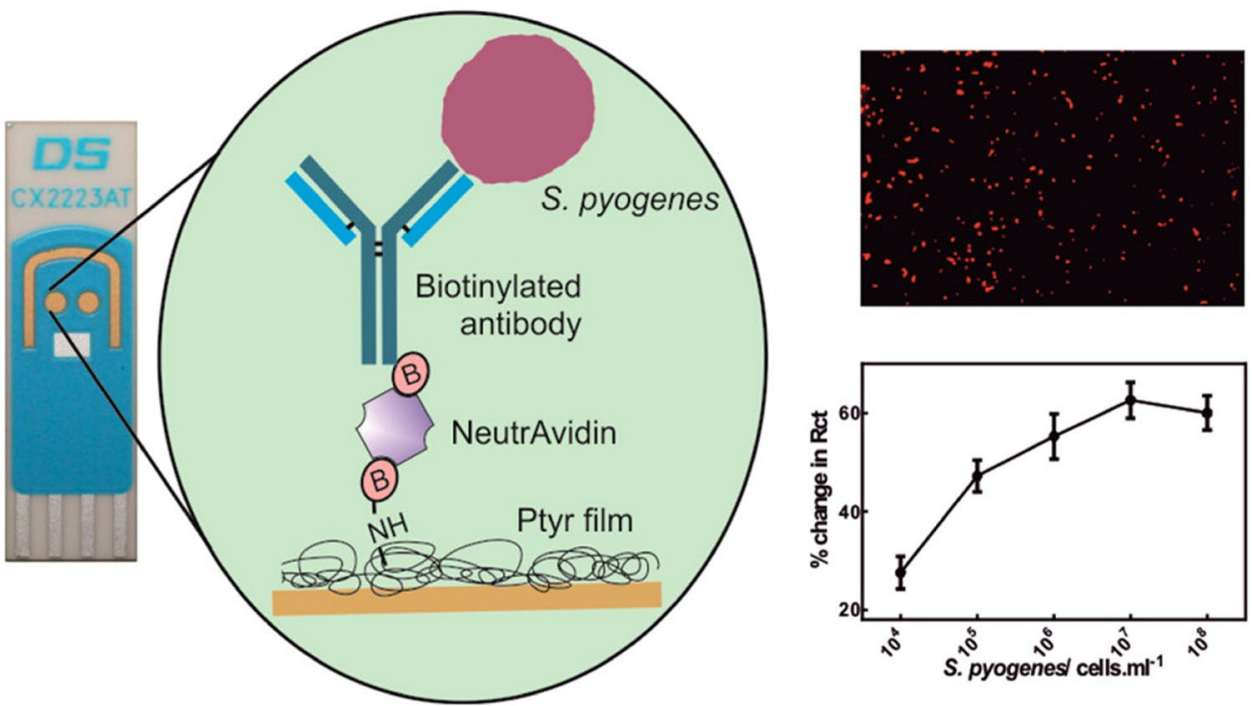
hypertension, obesity, hyperlipidemia and stress. According to epidemiological studies, preventive measures are the best treatment for CVD [90]. This fact leads to monitor different biomarkers related with CVD for early diagnostics.

Myocardial infarction (AMI) requires of a rapid and accurate diagnostic. Myoglobin (Mb), cardiac troponins (cTn), creatine kinase MB (CK-MB) and myeloperoxidase (MPO) are indicators of elevated risk of AMI. In 2010, an impedimetric immunosensor for $\mathrm{Mb}$ was constructed over a flat gold wire (Fig. 9). Myoglobin, which consists of a $17.8 \mathrm{kDa}$ protein, was detected in aqueous solution over linear range from 10 to $650 \mathrm{ng} / \mathrm{mL}$, with an LOD of $5.2 \mathrm{ng} / \mathrm{mL}$ [91]. Further impedimetric immunosensors for $\mathrm{Mb}$ have been developed. An impedimetric immunosensor for $\mathrm{Mb}$ was achieved by [92], reaching an LOD of $1.70 \mathrm{ng} / \mathrm{mL}$ and could detect a linear range from 0.01 to $1 \mu \mathrm{g} / \mathrm{mL}$ in less than $15 \mathrm{~min}$ for samples in PBS. Several novel components were included in the biosensor architecture. An indium-tin-oxide (ITO) glass plate was employed as electrode platform, in which a SAM was deposited and then functionalized with platinum nanoparticles prior to antibody attachment. However, the most sensitive impedimetric immunosensor for $\mathrm{Mb}$ was achieved by [93], in which Screen-printed multi-walled carbon nanotubes electrodes (MWCNTs) [94] could improve the sensitivity of Mb detection. An LOD of $0.08 \mathrm{ng} / \mathrm{mL}$ could be achieved and a linear range from $0.1 \mathrm{ng} / \mathrm{mL}$ to $90 \mathrm{ng} / \mathrm{mL}$ could be detected in $5 \mu \mathrm{L}$ samples. Several novel components were included in the biosensor architecture. An indium-tin-oxide (ITO) glass plate was employed as electrode platform, in which a SAM was deposited and then
Fig. 9 a Scheme of the biosensor construction for $\mathrm{Mb}$ detection. A flat gold wire is used as electrode to be functionalized with anti-Mb, blocked with BSA, and finally tested with $\mathrm{Mb}$; b shows the impedance values for each step of the biosensor construction; and c the impedance values shown through a Nyquist plot for increasing concentration of the analyte. Reprinted from [91], with permission from Elsevier
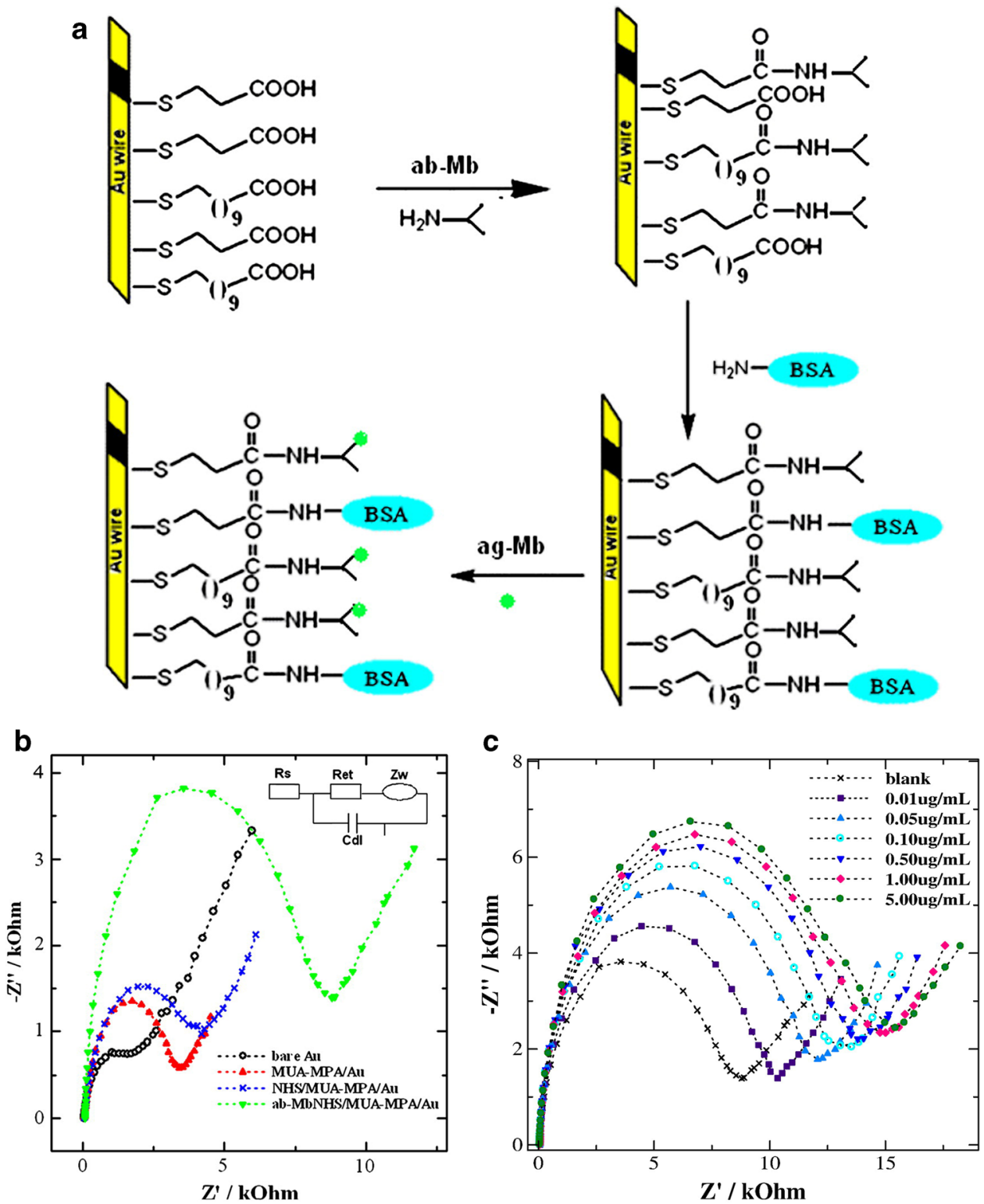
functionalized with platinum nanoparticles prior to antibody attachment. Other CVD biomarkers have also been detected though impedimetric biosensing. Cardiac troponin I (cTnI), which is used as a definitive biomarker for AMI diagnosis and soluble lectin-like oxidized LDL receptor-1 (sLOX-1), which serves as a biomarker for early diagnostic of AMI and acute coronary syndrome (ACS), were detected in PBS and in serum samples. The sensitivity of the final sensor could detect an LOD of $10^{-13} \mathrm{M}$ for each analyte [95]. A more recent investigation, lead to a better biosensor platform for cTnI detection. An LOD of $11.7 \mathrm{fM}$ was achieved and a linear range from $42 \mathrm{fM}$ to $42 \mathrm{nM}$ could be detected in approximately $1 \mathrm{~h} \mathrm{[96].} \mathrm{The} \mathrm{biosensor} \mathrm{construction} \mathrm{included}$ the addition of dendrimer before antibody attachment, which improved the LOD over 120 times. The reliability of the biosensor prototype was checked in parallel with ELISA, and resulted in a robust method for cTnI detection in serum. Biosensors have also reached other diseases such as deep vein thrombosis (DVT), which is typically indicated by the appearance of D-dimer. A platform based on a gold microelectrode was functionalized with single-walled carbon nanotubes (SWCN) and anti-D-dimer in order to detect the mentioned molecules at levels of $0.1 \mathrm{pg} / \mathrm{mL}(53 \mathrm{fM})$ in less than $10 \mathrm{~min}$ [97].

\section{Biomarkers for cancer}

Several types of cancer such as ovarian, breast and pancreatic cancer can be early detected by assessing the levels of the protein human epidermal growth factor receptor (EGFR). A disposable CNT based biosensor was developed and could detect EGFR at low levels such as $2 \mathrm{fg} / \mathrm{mL}$, improving the LOD of $4 \mathrm{pg} / \mathrm{mL}$ provided by commercial kits by then [98]. Another biosensor for EFGR detection was developed by depositing AuNPs and LODs of $0.34 \mathrm{pg} / \mathrm{mL}$ and $0.88 \mathrm{pg} /$ $\mathrm{mL}$ were achieved for samples in PBS and in human plasma respectively [99]. Clinical observational methods have demonstrated that 1 out of 3 men over 50 years old have evidence of histologic prostate cancer, although in a several number of cases the tumour is small and insignificant [100]. Then, it is important to develop rapid detection platforms for early-diagnosis. A gold microelectrode was used a platform to construct an impedimetric immunosensor for prostatespecific antigen (PSA) detection and quantification, which is a biomarker overexpressed in prostate cancer. An LOD in the order of $\mathrm{ng} / \mathrm{mL}$ was achieved [101].

The progression of ovarian cancer can be followed by monitoring the serum oncomarker cancer antigen 125 (CA125). For that, an impedimetric immunosensor for CA- 125 determination was developed over a gold electrode platform that was previously functionalized with silica coated gold nanoparticles and quantum dots [102, 103]. The system could detect CA-125 in serum of ovarian cancer patients with an LOD of $0.0016 \mathrm{U} / \mathrm{mL}$ in less than $1 \mathrm{~h}$ [104]. Negative regulator protein murine double minute 2 (MDM2) serves as a tumour brain marker. A biosensor for MDM2 was develop to detect this protein in health mice and mice with brain tumours. For that, a biosensing platform was built over a polycrystalline gold electrode. MDM2 biomarker was detected in PBS and brain homogenate samples, with an LOD of $0.29 \mathrm{pg} / \mathrm{mL}$ and $1.3 \mathrm{pg} / \mathrm{mL}$ respectively, both in less than $1 \mathrm{~h}$, and thus improving the detection time of commercial kits which last for $5 \mathrm{~h}$ [105]. Paediatric adrenocortical carcinoma (pACC) is an unusual cancer typically found in South America. It is characterized for the high production of dehydroepiandrosterone sulphate (DHEAS). This pACC biomarker was detected by developing a biosensor over an oxidised glassy carbon electrode that was functionalized with AuNPs. An LOD of $7.4 \mu \mathrm{g} / \mathrm{dL}$ in blood serum samples was achieved [106].

\section{Biomarkers for bacterial and other diseases}

Triggering receptor-1 expressed (TREM-1) is a biomarker which indicates a response to bacterial sepsis, whilst $\mathrm{N}$-3-oxo-dodecanoyl-L-homoserine lactone (HSL) is present in pathogenic wound infections. Therefore, the need for a rapid detection of these molecules can be crucial for a fast response towards wound infection. The construction of an impedimetric immunosensor for these biomarkers was accomplished [52]. Gold SPEs were modified with antibodies and the detection was achieved in less than $1 \mathrm{~h}$ in a $10 \mu \mathrm{L}$ mock wound samples. LODs were $3.3 \mathrm{pM}$ for TREM-1 and $1.4 \mathrm{nM}$ for HSL, which are near or below the limits required to consider the presence of infection.

Tuberculosis is one of the most prevalent and important worldwide diseases due to its virulence and death rate among the centuries. This disease is caused by Mycobacterium tuberculosis, which affects mammals and it is estimated to cause the death of 2 million people per year. Physical examination, chest X-ray as well as bacterial cultures are some of the routine diagnosis procedures. A biosensor included into a microfluidic platform [107] detected samples of human and bovine tuberculosis at concentrations as low as $10 \mathrm{ng} / \mathrm{mL}$ in a $10 \mu \mathrm{L}$ sample. The test lasted for $10 \mathrm{~min}$ without the need to modify the electrode surface since antibodies were attached to the surface by passive adsorption. Other biosensors for CD14 and CD16 monocyte detection as indicators of infectious state were also reported [108].

\section{Other bioreceptors}

There are several proteins derived from antibodies such as nanobodies. Nanobodies are single-domain antibody fragments found in camelids [109], which have demonstrated to properly work as bioreceptors. A biosensor using nanobodies 
Table 1 A summarize of the different impedimetric immunosensors found in the literature

\begin{tabular}{|c|c|c|c|c|c|c|}
\hline $\begin{array}{l}\text { Immunosensor } \\
\text { electrode }\end{array}$ & Analyte & Immobilisation step & LOD & Sample volume & Detection time & References \\
\hline $\mathrm{Au}$ IDAM & E. coli O157:H7 & MNAC/SA/BT/Ab & $\begin{array}{l}-1.2 \times 10^{3} \mathrm{cfu} / \mathrm{mL} \\
\text { from ground beef } \\
\text { samples } \\
-1.6 \times 10^{2} \mathrm{cfu} / \mathrm{mL} \\
\text { from pure culture }\end{array}$ & $100 \mu \mathrm{L}$ & $35 \mathrm{~min}$ & {$[54]$} \\
\hline $\mathrm{Au}$ & E. coli O157:H7 & $\mathrm{MACA} / \mathrm{EDC}+\mathrm{NHS} / \mathrm{Ab}$ & $\begin{array}{l}1 \times 10^{3} \mathrm{cfu} / \mathrm{mL} \text { in } \\
\text { culture }\end{array}$ & $20 \mu \mathrm{L}$ & $1 \mathrm{~h}$ & {$[57]$} \\
\hline $\mathrm{Au}$ & E. coli O157:H7 & $\begin{array}{l}\text { MHDA/ } \\
(\mathrm{EDC}+\mathrm{PFP}+\mathrm{DIEA}) / \\
\mathrm{Ab} / \mathrm{AEE}\end{array}$ & $2 \mathrm{cfu} / \mathrm{mL}$ & - & $45 \mathrm{~min}$ & {$[27]$} \\
\hline Pt wire & $\begin{array}{l}\text { E. coli O157:H7 / } \\
\text { Staphylococcus } \\
\text { aureus }\end{array}$ & NAM/GPMS/Ab & $10^{2} \mathrm{cfu} / \mathrm{mL}$ & - & $2 \mathrm{~h}$ & [59] \\
\hline $\mathrm{Ag} / \mathrm{AgCl}$ & E. coli O157:H7 & $\begin{array}{l}\text { NAM/HA/EDC + NHS/ } \\
\mathrm{Ab}\end{array}$ & $83.7 \mathrm{cfu} / \mathrm{mL}$ in milk & - & - & {$[61]$} \\
\hline Au microelectrode & E. coli O157:H7 & $\mathrm{PANI} / \mathrm{GLU} / \mathrm{Ab}$ & $10^{2} \mathrm{cfu} / \mathrm{mL}$ & _ & - & {$[62]$} \\
\hline $\mathrm{Au}$ & E. coli $0157: H 7$ & $\begin{array}{l}\text { 11M1UD/ECD/HA/ } \\
\mathrm{EDC}+\mathrm{NHS} / \mathrm{Ab}\end{array}$ & $7 \mathrm{cfu} / \mathrm{mL}$ & $1 \mathrm{~mL}$ & - & {$[2]$} \\
\hline rGOP & E. coli $0157: H 7$ & $\mathrm{Au}-\mathrm{NPs} / \mathrm{SA} / \mathrm{BT} / \mathrm{Ab} / \mathrm{BSA}$ & $\begin{array}{l}-1.5 \times 10^{3} \mathrm{cfu} / \mathrm{mL} \\
\text { cucumber } \\
-1.5 \times 10^{4} \mathrm{cfu} / \\
\text { mL ground beef } \\
\text { samples }\end{array}$ & - & - & {$[53]$} \\
\hline $\mathrm{Au}$ & E. coli O157:H7 & $\begin{array}{l}\text { MUA/EDC + NHS/Ab/ } \\
\text { AuNPs }\end{array}$ & $10^{2} \mathrm{cfu} / \mathrm{mL}$ & - & $2 \mathrm{~h}$ & {$[65]$} \\
\hline Au SPIM & E. coli O157:H7 & $\begin{array}{c}\text { DTSP/EDC + NHS/SA/ } \\
\text { BT/Ab/BSA/WGA }\end{array}$ & $10^{2} \mathrm{cfu} / \mathrm{mL}$ & - & $<1 \mathrm{~h}$ & {$[66]$} \\
\hline $\mathrm{Au}$ SPIM & E. coli O157:H7 & MgNbs/SA/Biotin/Ab & $1.4 \times 10^{3} \mathrm{cfu} / \mathrm{mL}$ & $25 \mu \mathrm{L}$ & _- & {$[67]$} \\
\hline ITO & E. coli $0157: H 7$ & GPMS/Ab & $1 \mathrm{cfu} / \mathrm{mL}$ & $400 \mu \mathrm{L}$ & $45 \mathrm{~min}$ & {$[68]$} \\
\hline Au-W microwire & E. coli $\mathrm{K} 12$ & $\mathrm{PEI} / \mathrm{SA} / \mathrm{BT} / \mathrm{Ab}$ & $10^{3} \mathrm{cfu} / \mathrm{mL}$ & $5 \mu \mathrm{L}$ & _ & {$[68]$} \\
\hline $\mathrm{Au}$ & E. coli $0157: H 7$ & $\begin{array}{l}\text { (Au-MBA-Ab), }(\mathrm{Au}- \\
\text { MBA-ProteinA/G-Ab), } \\
\text { (Au-Cys-Ab), }(\mathrm{Au}- \\
\text { Cys-Ferrocene-Ab), } \\
\text { (Au-Cys-PAMAM- } \\
\text { Ferrocene-Ab) }\end{array}$ & $3 \mathrm{cfu} / \mathrm{mL}$ & $1 \mathrm{~mL}$ & $90 \mathrm{~min}$ & {$[3]$} \\
\hline $\mathrm{Au}$ & S. typhimurium & Ptyr/GLU/Ab/BSA & $\begin{array}{l}-10 \mathrm{cfu} / \mathrm{mL} \text { in } \\
\text { culture } \\
-10^{2} \text { in milk }\end{array}$ & $2 \mathrm{~mL}$ & $\begin{array}{l}3 \mathrm{~h}, 10 \mathrm{~h} \text { respec- } \\
\text { tively }\end{array}$ & {$[71]$} \\
\hline Au SPE & S. typhimurium & Cys/Glu/Ab/BSA & $\begin{array}{l}-10^{3} \mathrm{cfu} / \mathrm{mL} \text { in } \\
\text { PBS } \\
-9 \times 10^{3} \text { in milk }\end{array}$ & $1 \mathrm{~mL}$ & $20 \mathrm{~min}$ & {$[72]$} \\
\hline Ti-Au IDAM & S. typhimurium & $\begin{array}{l}\text { MUA/EDC + NHS/Ab/ } \\
\text { BSA }\end{array}$ & $10^{3} \mathrm{cfu} / \mathrm{mL}$ & - & $30 \mathrm{~min}$ & [73] \\
\hline $\mathrm{Au}$ IDAM & S. typhimurium & 16-MHDA/SA/BT/Ab & $10^{2} \mathrm{cfu}$ & $50 \mu \mathrm{L}$ & $1 \mathrm{~h}$ & [74] \\
\hline $\begin{array}{l}\text { Pt interdigitated } \\
\text { microelectrodes }\end{array}$ & S. typhi & Au-NPs/AbPEG-thiol & $10^{2} \mathrm{cfu} / \mathrm{mL}$ & $10 \mu \mathrm{L}$ & $1 \mathrm{~h}$ & {$[75]$} \\
\hline $\mathrm{Au}$ & SRB & $\begin{array}{l}\text { MUA/EDC + NHS/ } \\
\text { lectin-ConA }\end{array}$ & $1.8 \mathrm{cfu} / \mathrm{mL}$ & - & $2 \mathrm{~h}$ & [76] \\
\hline Foam Ni & SRB & $\begin{array}{l}\text { AuNPs/11-MUA/ } \\
\text { EDC + NHS/Ab/BSA }\end{array}$ & $2.1 \times 10^{1} \mathrm{cfu} / \mathrm{mL}$ & - & $2 \mathrm{~h}$ & {$[78]$} \\
\hline Glassy carbon disc & SRB & $\mathrm{CS}+\mathrm{RGS} / \mathrm{Glu} / \mathrm{Ab} / \mathrm{BSA}$ & $1.8 \times 10^{1} \mathrm{cfu} / \mathrm{mL}$ & $10 \mu \mathrm{L}$ & $1 \mathrm{~h}$ & [79] \\
\hline Au microelectrode & L. monocytogenes & $\begin{array}{l}\mathrm{TiO} 2 \text { nanowire/(SH- } \\
(\mathrm{CH} 2) 3-\mathrm{CH} 3) / \mathrm{Ab}\end{array}$ & $4.7 \times 10^{2} \mathrm{cfu} / \mathrm{mL}$ & $15 \mu \mathrm{L}$ & $50 \mathrm{~min}$ & {$[82]$} \\
\hline
\end{tabular}


Table 1 (continued)

\begin{tabular}{|c|c|c|c|c|c|c|}
\hline $\begin{array}{l}\text { Immunosensor } \\
\text { electrode }\end{array}$ & Analyte & Immobilisation step & LOD & Sample volume & Detection time & References \\
\hline IDAM & L. monocytogenes & MNPs/SA/BT/Ab & $\begin{array}{l}10^{4} \mathrm{cfu} / \mathrm{mL} \text { in milk, } \\
\text { beef and lettuce }\end{array}$ & $20 \mathrm{~nL}$ & $3 \mathrm{~h}$ & {$[83]$} \\
\hline SPCE & P. aeruginosa & $\mathrm{PP} 3 \mathrm{CA} / \mathrm{EDC}+\mathrm{NHS} / \mathrm{Ab}$ & $10 \mathrm{cfu} / \mathrm{mL}$ & & - & [84] \\
\hline Au SPE & S. pyogenes & $\begin{array}{l}\mathrm{Ptyr} / \mathrm{BT} / \mathrm{NA} / \mathrm{BT} / \mathrm{Ab} / \\
\mathrm{BSA}\end{array}$ & $10^{2} \mathrm{cfu} / \mathrm{ml}$ & $10 \mu \mathrm{L}$ & $30 \mathrm{~min}$ & [41] \\
\hline $\mathrm{Au}$ & S. aureus & $\mathrm{MHDA} / \mathrm{EDC}+\mathrm{NHS} / \mathrm{Ab}$ & $10 \mathrm{cfu} / \mathrm{mL}$ & $5 \mathrm{~mL}$ & - & {$[85]$} \\
\hline $\mathrm{Au}$ IDAM & AI virus H5N1 & Protein A/Ab/BSA & $\begin{array}{l}\text { titer higher than } 10^{3} \\
\text { EID }_{50} / \mathrm{mL}\end{array}$ & $50 \mu \mathrm{L}$ & $2 \mathrm{~h}$ & [86] \\
\hline Au IDAM & AI virus $\mathrm{H} 5 \mathrm{~N} 1$ & Protein $\mathrm{A} / \mathrm{Ab} / \mathrm{BSA}$ & $2^{-1} \mathrm{HAU} / 50 \mu \mathrm{L}$ & $30 \mu \mathrm{L}$ & $45 \mathrm{~min}$ & {$[38]$} \\
\hline $\mathrm{Au}$ & Ad5 & $\begin{array}{l}\text { 1,6-HDT/AuNPs/MUA/ } \\
\text { EDC + NHS/Ab }\end{array}$ & $\begin{array}{l}30 \text { virus particles/ } \\
\mathrm{mL}\end{array}$ & $200 \mu \mathrm{L}$ & - & [87] \\
\hline $\mathrm{Au}$ & PPV & $\begin{array}{l}\text { 1,6-HDT/AuNPs/Ab/ } \\
\text { BSA }\end{array}$ & $10 \mathrm{pg} / \mathrm{mL}$ & - & $30 \mathrm{~min}$ & [88] \\
\hline Pt wire & $\begin{array}{l}\text { Aphanomyces } \\
\text { invadans }\end{array}$ & $\begin{array}{l}\text { G-AuNPs/SAM-Ab- } \\
\text { BSA/GCE }\end{array}$ & $309 \mathrm{ng} / \mathrm{mL}$ & - & $10 \mathrm{~min}$ & [89] \\
\hline Au SPE & $\begin{array}{l}\text { TREM-1/MMP-9/ } \\
\text { HSL }\end{array}$ & Thiolated Ab & $\begin{array}{l}-3.3 \mathrm{pM} \text { for } \\
\text { TREM-1 } \\
-1.1 \mathrm{nM} \text { for } \\
\text { MMP-9 from } \\
\text { mock wound fluid } \\
-1.4 \mathrm{nM} \text { for HSL }\end{array}$ & $10 \mu \mathrm{L}$ & $<1 \mathrm{~h}$ & {$[52]$} \\
\hline $\mathrm{Au}$ & $\mathrm{cTnI} / \mathrm{sLOX}-1$ & $\begin{array}{l}\text { 16-MHDA/BT-caproyl- } \\
\text { DPPE species/NA/ } \\
\text { BT/Ab }\end{array}$ & $\begin{array}{l}10^{-13} \mathrm{M} \text { each ana- } \\
\text { lyte in PBS and } \\
\text { serum }\end{array}$ & - & $30 \mathrm{~min}$ & [112] \\
\hline IDAM & hTB antigen & Ab/blocking buffer & $10 \mathrm{ng} / \mathrm{mL}$ & $10 \mu \mathrm{L}$ & $10 \mathrm{~min}$ & [107] \\
\hline $\mathrm{Au}$ & $\begin{array}{l}\text { CD14/CD16 mono- } \\
\text { cytes }\end{array}$ & $\begin{array}{l}\text { MUA-MH/Proteing G/ } \\
\text { BSA/Ab }\end{array}$ & $10^{3} \mathrm{cfu} / \mathrm{ml}$ & $1 \mathrm{~mL}$ & $2 \mathrm{~h}$ & [108] \\
\hline Flat $\mathrm{Au}$ wire & $\mathrm{Mb}$ & $\begin{array}{l}\text { MUA-MPA/EDC-NHS/ } \\
\text { Ab-Mb/BSA }\end{array}$ & $5.2 \mathrm{ng} /$ & - & - & {$[91]$} \\
\hline $\begin{array}{l}\text { Screen-printed } \\
\text { MWCNTs }\end{array}$ & $\mathrm{Mb}$ & $\mathrm{Ab}-\mathrm{Mb} / \mathrm{BSA}$ & $0.08 \mathrm{ng} / \mathrm{mL}$ & $5 \mu \mathrm{L}$ & - & [93] \\
\hline $\begin{array}{l}\text { ITO coated glass } \\
\text { plates }\end{array}$ & $\mathrm{Mb}$ & $\begin{array}{l}\text { APTES/EDC-NHS/ } \\
\text { Pt(MPA)/Ab-cMb/ } \\
\text { BSA }\end{array}$ & $1.70 \mathrm{ng} / \mathrm{mL}$ & & $12 \min$ & [94] \\
\hline $\mathrm{Au}$ & cTnI & $\begin{array}{c}\text { (MHA)/EDC-NHS/ } \\
\text { TMB/EDCH-NHS-/ } \\
\text { Dendrimer/Ab/BSA }\end{array}$ & $\begin{array}{l}11.7 \pm 0.62 \mathrm{fM} \\
(0.28 \pm 0.015 \mathrm{pg} / \\
\mathrm{mL})\end{array}$ & - & $1 \mathrm{~h}$ & [96] \\
\hline Au microelectrode & D-dimer & $\begin{array}{l}\text { SWCN-COOH/Ab/ } \\
\text { Casein }\end{array}$ & $0.1 \mathrm{pg} / \mathrm{mL}(0.53 \mathrm{fM})$ & - & $10 \mathrm{~min}$ & [97] \\
\hline SWCNT SPE & EGFR & $\begin{array}{l}\text { CNT/EDC/NHS/Ab/ } \\
\text { BSA }\end{array}$ & $2 \mathrm{fg} / \mathrm{mL}$ & - & - & [98] \\
\hline $\mathrm{Au}$ & EGFR & $\begin{array}{l}\text { AuNPS/Cys/PDITC/ } \\
\text { Proteing G/Ab }\end{array}$ & $\begin{array}{l}-0.34 \mathrm{pg} / \mathrm{mL} \text { in } \\
\text { PBS } \\
-0.88 \mathrm{pg} / \mathrm{mL} \text { in } \\
\text { human plasma }\end{array}$ & - & $1 \mathrm{~h}$ & [99] \\
\hline Au microelectrode & PSA & $\begin{array}{l}\text { 16MHDA/EG3SH/ } \\
\text { EDC-NHS/Amine- } \\
\text { PEG-BT/Avidin-(BT } \\
\text { Ab-Ag Psa-HRP Ab) }\end{array}$ & $\begin{array}{l}-0.51 \mathrm{ng} / \mathrm{mL} \text { for } \\
\text { t-PSA } \\
-0.07 \mathrm{ng} / \mathrm{mL} \text { for } \\
\text { f-PSA }\end{array}$ & - & - & {$[101]$} \\
\hline $\mathrm{Au}$ & CA-125 & $\begin{array}{l}\text { MPA/EDC-NHS/ } \\
\text { AuNP@SiO2/QDs/ } \\
\text { mAb }\end{array}$ & $\begin{array}{l}0.0016 \mathrm{U} / \mathrm{mL} \text { in } \\
\text { serum of ovarian } \\
\text { cancer patients }\end{array}$ & - & $<1 \mathrm{~h}$ & [104] \\
\hline
\end{tabular}


Table 1 (continued)

\begin{tabular}{|c|c|c|c|c|c|c|}
\hline $\begin{array}{l}\text { Immunosensor } \\
\text { electrode }\end{array}$ & Analyte & Immobilisation step & LOD & Sample volume & Detection time & References \\
\hline Polycrystaline $\mathrm{Au}$ & MDM2 & $\begin{array}{l}\text { Cysteamine (CA) } \\
\text { SAM/1,4-phenylene } \\
\text { diisothiocyanate } \\
\text { (PDITC)/Ab/EA }\end{array}$ & $0.29 \mathrm{pg} / \mathrm{mL}$ & - & - & [105] \\
\hline Oxidised GCE & DHEAS & $\begin{array}{c}\text { ox-GCE/AuNPs-ARG/ } \\
\text { Ab/EDC/NHS/BSA }\end{array}$ & $\begin{array}{c}7.4 \mu \mathrm{g} / \mathrm{dL} \text { in blood } \\
\text { plasma samples }\end{array}$ & - & - & [106] \\
\hline GCE & Testosterone & $\begin{array}{l}\text { EDC-NHS/SA/BSA/ } \\
\text { Nanobody }\end{array}$ & $0.045 \mathrm{ng} / \mathrm{mL}$ & $20 \mu \mathrm{L}$ & $1 \mathrm{~h}$ & [110] \\
\hline $\mathrm{Au}$ & Rabbit IgG & $\begin{array}{l}\text { Ptyr/Sulfo-SMCC/Nano- } \\
\text { body }\end{array}$ & $666 \mathrm{fM}$ & $10 \mu \mathrm{L}$ & $30 \mathrm{~min}$ & [111] \\
\hline $\mathrm{Au} \mathrm{ID} \mu \mathrm{E}$ & Her4 tumour protein & $\begin{array}{l}\text { Cys-Her4 Affimer/PBS- } \\
\text { tween } 20 \text { based start- } \\
\text { ing block (SB)/Her4 }\end{array}$ & $\begin{array}{l}<1 \mathrm{pM} \text { in buffer } \\
\text { and in serum }\end{array}$ & - & $30 \mathrm{~min}$ & [112] \\
\hline
\end{tabular}

Different components, steps and features of the biosensors are showed, namely: immunosensor electrode, analyte, immobilisation step, LOD and sample volume

1,6HDT 1,6-hexanedithiol, 11M1UD 11-Mercapto-1-undecanol, 16MHDA 16-Mercaptohexadecanoic, 2M2P 2-methyl-2-propanethiol, Ab antibody, AEE 2-(2-aminoethoxy) ethanol, APTES 3-aminopropyltriethoxy silane, $A u N P @ S i O_{2}$ silica coated gold nanoparticles, bTB bovine tuberculosis, $B C N T$ - $I L$ bamboo-like multiwall carbon nanotubes-ionic liquid, $B S A$ bovine serum albumina, $B T$ biotin, $C A-125$ cancer antigen 125, ConA concanavalin A, CS chitosan, $c T n I$ Cardiac troponin I, DHEAS dehydroepiandrosterone sulfate, DIEA N,N-diisopropylethylamine, $D T S P$ 3-dithiobis-(sulfosuccinimidyl-propionate), EA ethanolamine, ECD epichlorohydrin, EG3SH tri(ethylene glycol), EGFR epidermal growth factor, $G$-AuNPs Graphene gold nanoparticles, $G C D$ glassy carbon disc, $G L U$ glutaraldehyde, GPMS (3-glycidoxypropyl)trimethoxysilane, $C y s$ cysteamine, $H A$ hyaluronic acid, $h T B$ human tuberculosis, $I D \mu E$ interdigitated micro-electrode, $M A C A$ mercaptoacetic acid, $M b$ myoglobin, $M B A$ 4-mercaptobenzoic acid, $M D M 2$ murine double minute 2, $M H$ 6-mercapto-1-hexanol, $M H D A$ mercaptohexadecanoic, $M g N b s$ magnetic nanobeads, $M g N P s$ magnetic nanoparticles, MNAC magnetic nanoparticle-antibody conjugates, MPA 3-mercapto propionic acid, MUA mercaptoundecanoic acid, $M W C N T$ multi-walled carbon nanotube, $N A M$ nanoporous alumina membrane, $N A$ neutravidin, PAMAM polyamidoamine, PANI polyaniline, PDITC 1,4-phenylene diisothiocyanate, PEG-thiol carboxy-thiolpolyethyleneglycol, PEI polyethyleneimine, $P F P$ 2,3,4,5,6-pentafluorophenol, $P O P D$ poly (ortho-phenylenediamine; PP3CA: poly(pyrrole-3-carboxylic acid), PSA prostate-specific antigen, PSSA polystyrene sulphonic acid, Ptyr polytyramine, $Q D s$ quantum dots, $r G O$ reduced graphene oxide, $r G O P$ reduced graphene oxide paper, $R G S$ reduced graphene sheets, $S A$ streptavidin, $S L O X-1$ soluble lectin-like oxidized low-density lipoprotein receptor-1, $S P C E$ screen-printed carbon electrode, SPE screen-printed electrode, SPIE screen-printed interdigitated electrode, Sulfo-SMCC sulfosuccinimidyl 4-[N-maleimidomethyl] cyclohexane-1-carboxylate, $S W C N$ single-walled carbon nanotube, $T M B$ 3,3',5,5'-tetramethyl benzidine, VACNT vertically aligned carbon nanotube, $W G A$ wheat germ agglutinin

was constructed over a glassy carbon electrode platform, and determined the concentration of testosterone in over $1 \mathrm{~h}$, achieving an LOD of $0.045 \mathrm{ng} / \mathrm{mL}$ [110]. Another case of nanobody-based impedimetric biosensor was constructed to detect rabbit $\mathrm{IgG}$, whose production is very demanded for its frequent use in companies [111].

Affimers are a non-antibody scaffolds considered as a good alternative as a binding protein [44]. An impedimetric biosensor based on Affimer binding bioreceptor was used to detect and quantify Her4 protein tumour, getting an LOD lower than $1 \mathrm{pM}$ in less than $30 \mathrm{~min}$ of sample incubation [112].

\section{Conclusion}

In short, the evolution of impedimetric immunosensor platforms has been analysed for different types of pathogens. Parameters of strong importance such as LOD, detection time and sample volume have been discussed and compared. Alternative to classical macro-sized electrodes such as IDAM or SPE, the introduction of nanostructures such as nanoparticles or nanoporous membranes and the insertion of the biosensor into a microfluidic chip have been relevant modifications to improve these platforms. Successful evolution of biosensors is occurring and currently diagnostic techniques are becoming replaced. All biosensors described are indicated in Table 1. Nevertheless, limitations such as the high cost of the electrodes and antibodies as well as reproducibility still remain a challenge when dealing with large scale applications. As a consequence, new antibody derived proteins such as nanobodies or non-antibody proteins such as Affimers are being investigated in this field.

Acknowledgements The author is funded by the European Union's Horizon 2020 Research and Innovation Programme under the Marie Sklodowska-Curie Grant agreement no. 765042.

Open Access This article is licensed under a Creative Commons Attribution 4.0 International License, which permits use, sharing, 
adaptation, distribution and reproduction in any medium or format, as long as you give appropriate credit to the original author(s) and the source, provide a link to the Creative Commons licence, and indicate if changes were made. The images or other third party material in this article are included in the article's Creative Commons licence, unless indicated otherwise in a credit line to the material. If material is not included in the article's Creative Commons licence and your intended use is not permitted by statutory regulation or exceeds the permitted use, you will need to obtain permission directly from the copyright holder. To view a copy of this licence, visit http://creativecommons .org/licenses/by/4.0/.

\section{References}

1. Aslam B et al (2018) Antibiotic resistance: a rundown of a global crisis. Infect Drug Resist 11:1645-1658

2. Joung CK, Kim HN, Im HC, Kim HY, Oh MH, Kim YR (2012) Ultra-sensitive detection of pathogenic microorganism using surface-engineered impedimetric immunosensor. Sens Actuators B Chem 161(1):824-831

3. Malvano F, Pilloton R, Albanese D (2018) Sensitive detection of Escherichia coli O157:H7 in food products by impedimetric immunosensors. Sensors (Switzerland) 18(7):1-11

4. Mantzila AG, Maipa V, Prodromidis MI (2008) Development of a faradic impedimetric immunosensor for the detection of Salmonella typhimurium in milk. Anal Chem 80(4):1169-1175

5. Tiede $\mathrm{C}$ et al (2017) Affimer proteins are versatile and renewable affinity reagents. Elife 6(c):1-35

6. Weiss S, Millner P, Nelson A (2005) Monitoring protein binding to phospholipid monolayers using electrochemical impedance spectroscopy. Electrochim Acta 50(21):4248-4256

7. O'Neill (2016) Tackling drug-resistant infections globally: Final report and recommendations. Review on antimicrobial resistance. https://amrreview.org/sites/default/files/160518_Final \%20paper_with\%20cover.pdf. Accessed May 2016

8. Bursle E, Robson J (2016) Non-culture methods for detecting infection. Aust Prescr 39(5):171-175

9. Sakamoto $S$ et al (2018) Enzyme-linked immunosorbent assay for the quantitative/qualitative analysis of plant secondary metabolites. J Nat Med 72(1):32-42

10. Croxen MA, Law RJ, Scholz R, Keeney KM, Wlodarska M, Finlay BB (2013) Recent advances in understanding enteric pathogenic Escherichia coli. Clin Microbiol Rev 26(4):822-880

11. Douterelo I, Boxall JB, Deines P, Sekar R, Fish KE, Biggs CA (2014) Methodological approaches for studying the microbial ecology of drinking water distribution systems. Water Res 65:134-156

12. Zhao X, Li M, Xu Z (2018) Detection of foodborne pathogens by surface enhanced Raman spectroscopy. Front Microbiol 9(JUN):1-13

13. Rushworth JV, Hirst NA, Goode JA, Pike D, Ahmed A, Millner P (2013) Impedimetric biosensors for medical applications: current progress and challenges. ASME, New York

14. Clark LC, Lyons C (1962) Electrode systems for continuous monitoring in cardiovascular surgery. Ann N Y Acad Sci 102(1):29-45

15. Oblath EA, Henley WH, Alarie JP, Ramsey JM (2013) A microfluidic chip integrating DNA extraction and real-time PCR for the detection of bacteria in saliva. Lab Chip 13(7):1325-1332

16. Chowdhury AD, Ganganboina AB, Park EY, An Doong R (2018) Impedimetric biosensor for detection of cancer cells employing carbohydrate targeting ability of Concanavalin A. Biosens Bioelectron 122(August):95-103
17. Wilson GS, Gifford R (2005) Biosensors for real-time in vivo measurements. Biosens Bioelectron 20(12):2388-2403

18. van Oss CJ, Good RJ, Chaudhury MK (2002) Nature of the antigen-antibody interaction. J Chromatogr B Biomed Sci Appl 376:111-119

19. Monošík R, Stred’anský M, Šturdík E (2012) Biosensors-classification, characterization and new trends. Acta Chim Slovaca 5(1):109-120

20. Yan XF, Wang MH, An D (2011) Progress of interdigitated array microelectrodes based impedance immunosensor. Fenxi Huaxue/ Chin J Anal Chem 39(10):1601-1610

21. Ligler F, Taitt C (2002) Optical biosensors: present \& future. Elsevier, Oxford

22. Borisov SM, Wolfbeis OS (2008) Optical biosensors. Chem Rev 108(2):423-461

23. Fan X, White IM, Shopova SI, Zhu H, Suter JD, Sun Y (2008) Sensitive optical biosensors for unlabeled targets: a review. Anal Chim Acta 620(1-2):8-26

24. Homola J, Yee SS, Gauglitz G (1999) Surface plasmon resonance sensors: review. Sens Actuators B Chem 54(1-2):3-15

25. Arlett JL, Myers EB, Roukes ML (2011) Comparative advantages of mechanical biosensors. Nat Nanotechnol 6(4):203-215

26. Bard AJ, Faulkner LR (2001) Electrochemical methods, 2nd edn. Wiley, New York

27. Koren ME, Papamiditriou C (2013) Spirituality of staff nurses: application of modeling and role modeling theory. Holist Nurs Pract 27(1):37-44

28. Chaubey A, Malhotra BD (2002) Review mediated biosensors. Biosens Bioelectron 7:441-456

29. Pisoschi AM (2016) Potentiometric biosensors: concept and analytical applications-an editorial. Biochem Anal Biochem 5(3):19-20

30. Barlett PN, Cooper JM (1993) A review of the immobilization of enzymes in electropolymerized films. J Electroanal Chem 362(1-2):1-12

31. Gottschalk A, Breulmann M, Fetter E, Kretschmer K, Bastian M (2006) PVC noch 'heier' gemacht. Kunststoffe Int 96(7):48-50

32. Wang J (2001) Glucose biosensors: 40 years of advances and challenges. Electroanalysis 13(12):983-988

33. Metkar SK, Girigoswami K (2019) Diagnostic biosensors in medicine-a review. Biocatal Agric Biotechnol 17:271-283

34. Vakurov A, Pchelintsev NA, Forde J, 'Fgin C, Gibson T, Millner $P$ (2009) The preparation of size-controlled functionalized polymeric nanoparticles in micelles. Nanotechnology 20(29):295605

35. Tothill IE, Newman JD, White SF, Turner APF (1997) Monitoring of the glucose concentration during microbial fermentation using a novel mass-producible biosensor suitable for on-line use. Enzyme Microb Technol 20(8):590-596

36. Hirst NA, Hazelwood LD, Jayne DG, Millner PA (2013) An amperometric lactate biosensor using $\mathrm{H}_{2} \mathrm{O}_{2}$ reduction via a Prussian Blue impregnated poly(ethyleneimine) surface on screen printed carbon electrodes to detect anastomotic leak and sepsis. Sens Actuators B Chem 186:674-680

37. Chiang WH, Chen PY, Nien PC, Ho KC (2011) Amperometric detection of cholesterol using an indirect electrochemical oxidation method. Steroids 76(14):1535-1540

38. Lin J et al (2015) An impedance immunosensor based on lowcost microelectrodes and specific monoclonal antibodies for rapid detection of avian influenza virus $\mathrm{H} 5 \mathrm{~N} 1$ in chicken swabs. Biosens Bioelectron 67:546-552

39. Randviir EP, Banks CE (2013) Electrochemical impedance spectroscopy: an overview of bioanalytical applications. Anal Methods 5(5):1098-1115

40. Dinçkaya E, Kinik Ö, Sezgintürk MK, Altuĝ Ç, Akkoca A (2011) Development of an impedimetric aflatoxin M1 biosensor based 
on a DNA probe and gold nanoparticles. Biosens Bioelectron 26(9):3806-3811

41. Ahmed A, Rushworth JV, Wright JD, Millner PA (2013) Novel impedimetric immunosensor for detection of pathogenic bacteria Streptococcus pyogenes in human saliva. Anal Chem 85(24): $12118-12125$

42. Conroy PJ, Hearty S, Leonard P, O'Kennedy RJ (2009) Antibody production, design and use for biosensor-based applications. Semin Cell Dev Biol 20(1):10-26

43. Song S, Wang L, Li J, Fan C, Zhao J (2008) Aptamer-based biosensors. TrAC Trends Anal Chem 27(2):108-117

44. Tiede $\mathrm{C}$ et al (2014) Adhiron: a stable and versatile peptide display scaffold for molecular recognition applications. Protein Eng Des Sel 27(5):145-155

45. Hou L, Cui Y, Xu M, Gao Z, Huang J, Tang D (2013) Graphene oxide-labeled sandwich-type impedimetric immunoassay with sensitive enhancement based on enzymatic 4-chloro-1-naphthol oxidation. Biosens Bioelectron 47:149-156

46. Kokkinos C, Economou A, Prodromidis MI (2016) Electrochemical immunosensors: critical survey of different architectures and transduction strategies. TrAC Trends Anal Chem 79:88-105

47. Bahadir EB, Sezgintürk MK (2016) A review on impedimetric biosensors. Artif Cells Nanomed Biotechnol 44(1):248-262

48. Alshaaer M, Shqair M, Abdelwahed HG, Abuhasel K, Toro MZ (2017) Stabilization of heavy oil fly ash (HFO) for construction and environmental purposes. Int J Appl Eng Res 12(4):488-497

49. Guan J-G, Miao Y-Q, Zhang Q-J (2004) Impedimetric biosensors. J Biosci Bioeng 97(4):219-226

50. Lvovich VF (2012) Impedance spectroscopy: applications to electrochemical and dielectric phenomena. Wiley, New York

51. Rushworth JV, Ahmed A, Griffiths HH, Pollock NM, Hooper NM, Millner PA (2014) A label-free electrical impedimetric biosensor for the specific detection of Alzheimer's amyloid-beta oligomers. Biosens Bioelectron 56:83-90

52. Ciani I et al (2012) Development of immunosensors for direct detection of three wound infection biomarkers at point of care using electrochemical impedance spectroscopy. Biosens Bioelectron 31(1):413-418

53. Wang Y, Ping J, Ye Z, Wu J, Ying Y (2013) Impedimetric immunosensor based on gold nanoparticles modified graphene paper for label-free detection of Escherichia coli O157: H7. Biosens Bioelectron 49:492-498

54. Varshney M, Li Y, Srinivasan B, Tung S (2007) A label-free, microfluidics and interdigitated array microelectrode-based impedance biosensor in combination with nanoparticles immunoseparation for detection of Escherichia coli $\mathrm{O} 157: \mathrm{H} 7$ in food samples. Sens Actuators B Chem 128(1):99-107

55. Samiei E, Tabrizian M, Hoorfar M (2016) A review of digital microfluidics as portable platforms for lab-on a-chip applications. Lab Chip 16(13):2376-2396

56. Varshney M, Li Y (2009) Interdigitated array microelectrodes based impedance biosensors for detection of bacterial cells. Biosens Bioelectron 24(10):2951-2960

57. Kim J, Woo YY, Moon J, Kim B (2008) A new wideband adaptive digital predistortion technique employing feedback linearization. IEEE Trans Microw Theory Tech 56(2):385-392

58. Solanki PR et al (2010) Self-assembled monolayer based impedimetric platform for food borne mycotoxin detection. Nanoscale 2(12):2811-2817

59. Tan F et al (2011) A PDMS microfluidic impedance immunosensor for E. coli O157:H7 and Staphylococcus aureus detection via antibody-immobilized nanoporous membrane. Sens Actuators B Chem 159(1):328-335

60. La Flamme KE et al (2007) Biocompatibility of nanoporous alumina membranes for immunoisolation. Biomaterials 28(16):2638-2645
61. Joung CK, Kim HN, Lim MC, Jeon TJ, Kim HY, Kim YR (2013) A nanoporous membrane-based impedimetric immunosensor for label-free detection of pathogenic bacteria in whole milk. Biosens Bioelectron 44(1):210-215

62. Chowdhury AD, De A, Chaudhuri CR, Bandyopadhyay K, Sen P (2012) Label free polyaniline based impedimetric biosensor for detection of E. coli O157:H7 bacteria. Sens Actuators B Chem 171-172:916-923

63. Huang CC, Chang HT (2006) Selective gold-nanoparticle-based 'turn-on' fluorescent sensors for detection of mercury(II) in aqueous solution. Anal Chem 78(24):8332-8338

64. Chen $\mathrm{K}$ et al (2012) $\mathrm{Hg}$ (II) ion detection using thermally reduced graphene oxide decorated with functionalized gold nanoparticles. Anal Chem 84(9):4057-4062

65. Wan J, Ai J, Zhang Y, Geng X, Gao Q, Cheng Z (2016) Signal-off impedimetric immunosensor for the detection of Escherichia coli O157:H7. Sci Rep 6:2-7

66. Li Z, Fu Y, Fang W, Li Y (2015) Electrochemical impedance immunosensor based on self-assembled monolayers for rapid detection of Escherichia coli O157:H7 with signal amplification using lectin. Sensors (Switzerland) 15(8):19212-19224

67. Wang R, Lum J, Callaway Z, Lin J, Bottje W, Li Y (2015) A label-free impedance immunosensor using screen-printed interdigitated electrodes and magnetic nanobeads for the detection of E. coli $\mathrm{O} 157: \mathrm{H} 7$. Biosensors 5(4):791-803

68. Barreiros dos Santos M et al (2015) Label-free ITO-based immunosensor for the detection of very low concentrations of pathogenic bacteria. Bioelectrochemistry 101:146-152

69. Lu L, Chee G, Yamada K, Jun S (2013) Electrochemical impedance spectroscopic technique with a functionalized microwire sensor for rapid detection of foodborne pathogens. Biosens Bioelectron 42(1):492-495

70. Dougan G, Baker S (2014) Salmonella enterica Serovar Typhi and the pathogenesis of typhoid fever. Annu Rev Microbiol 68(1):317-336

71. Pournaras AV, Koraki T, Prodromidis MI (2008) Development of an impedimetric immunosensor based on electropolymerized polytyramine films for the direct detection of Salmonella typhimurium in pure cultures of type strains and inoculated real samples. Anal Chim Acta 624(2):301-307

72. Farka Z, Juřík T, Pastucha M, Kovář D, Lacina K, Skládal P (2016) Rapid immunosensing of Salmonella typhimurium using electrochemical impedance spectroscopy: the effect of sample treatment. Electroanalysis 28(8):1803-1809

73. Nguyen PD, Tran TB, Nguyen DTX, Min J (2014) Magnetic silica nanotube-assisted impedimetric immunosensor for the separation and label-free detection of Salmonella typhimurium. Sens Actuators B Chem 197:314-320

74. Wen T, Wang R, Sotero A, Li Y (2017) A portable impedance immunosensing system for rapid detection of Salmonella typhimurium. Sensors (Switzerland) 17(9):1-15

75. Pal N, Sharma S, Gupta S (2016) Sensitive and rapid detection of pathogenic bacteria in small volumes using impedance spectroscopy technique. Biosens Bioelectron 77:270-276

76. Wan Y, Zhang D, Hou B (2009) Monitoring microbial populations of sulfate-reducing bacteria using an impedimetric immunosensor based on agglutination assay. Talanta 80(1):218-223

77. Lis H, Sharon N (1998) Lectins: carbohydrate-specific proteins that mediate cellular recognition. Chem Rev 98(2):637-674

78. Wan Y, Zhang D, Wang Y, Hou B (2010) A 3D-impedimetric immunosensor based on foam Ni for detection of sulfate-reducing bacteria. Electrochem Commun 12(2):288-291

79. Wan Y, Lin Z, Zhang D, Wang Y, Hou B (2011) Impedimetric immunosensor doped with reduced graphene sheets fabricated by controllable electrodeposition for the non-labelled detection of bacteria. Biosens Bioelectron 26(5):1959-1964 
80. Yang J, Deng S, Lei J, Ju H, Gunasekaran S (2011) Electrochemical synthesis of reduced graphene sheet-AuPd alloy nanoparticle composites for enzymatic biosensing. Biosens Bioelectron 29(1):159-166

81. Drevets DA, Bronze MS (2008) Listeria monocytogenes: epidemiology, human disease, and mechanisms of brain invasion. FEMS Immunol Med Microbiol 53(2):151-165

82. Wang R et al (2008) $\mathrm{TiO}_{2}$ nanowire bundle microelectrode based impedance immunosensor for rapid and sensitive detection of Listeria monocytogenes. Nano Lett 8(9):2625-2631

83. Kanayeva DA et al (2012) Efficient separation and sensitive detection of Listeria monocytogenes using an impedance immunosensor based on magnetic nanoparticles, a microfluidic chip, and an interdigitated microelectrode. J Food Prot 75(11):1951-1959

84. Bekir K et al (2015) An investigation of the well-water quality: immunosensor for pathogenic Pseudomonas aeruginosa detection based on antibody-modified poly(pyrrole-3 carboxylic acid) screen-printed carbon electrode. Environ Sci Pollut Res 22(23): 18669-18675

85. Bekir K et al (2015) Electrochemical impedance immunosensor for rapid detection of stressed pathogenic Staphylococcus aureus bacteria. Environ Sci Pollut Res 22(20):15796-15803

86. Wang R et al (2009) Interdigitated array microelectrode based impedance immunosensor for detection of avian influenza virus H5N1. Talanta 79(2):159-164

87. Lin D, Tang T, Harrison DJ, Lee WE, Jemere AB (2015) A regenerating ultrasensitive electrochemical impedance immunosensor for the detection of adenovirus. Biosens Bioelectron 68:129-134

88. Jarocka U, Wasowicz M, Radecka H, Malinowski T, Michalczuk L, Radecki J (2011) Impedimetric immunosensor for detection of plum pox virus in plant extracts. Electroanalysis 23(9):2197-2204

89. Qi X, Chen T, Lu D, Chen B (2017) Graphene-Au nanoparticle based electrochemical immunosensor for fish pathogen Aphanomyces invadans detection. Fuller Nanotub Carbon Nanostruct 25(1):12-16

90. Lennon RP, Claussen KA, Kuersteiner KA (2018) State of the heart: an overview of the disease burden of cardiovascular disease from an epidemiologic perspective. Prim Care Clin Off Pract 45(1):1-15

91. Sharma RV, Tanwar VK, Mishra SK, Biradar AM (2010) Electrochemical impedance immunosensor for the detection of cardiac biomarker Myogobin (Mb) in aqueous solution. Thin Solid Films 519(3):1167-1170

92. Mishra SK, Srivastava AK, Kumar D (2014) Bio-functionalized Pt nanoparticles based electrochemical impedance immunosensor for human cardiac myoglobin. RSC Adv 4(41):21267-21276

93. Khan R, Pal M, Kuzikov AV, Bulko T, Suprun EV, Shumyantseva VV (2016) Impedimetric immunosensor for detection of cardiovascular disorder risk biomarker. Mater Sci Eng C 68:52-58

94. Thostenson ET, Ren Z, Chou TW (2001) Advances in the science and technology of carbon and their composites: a review. Compos Sci Technol 61(13):1899-1912

95. Billah MM, Hays HCW, Hodges CS, Ponnambalam S, Vohra R, Millner PA (2012) Mixed self-assembled monolayer (mSAM) based impedimetric immunosensors for cardiac troponin i (cTnI) and soluble lectin-like oxidized low-density lipoprotein receptor-1 (sLOX-1). Sens Actuators B Chem 173:361-366

96. Akter R, Jeong B, Lee YM, Choi JS, Rahman MA (2017) Femtomolar detection of cardiac troponin I using a novel label-free and reagent-free dendrimer enhanced impedimetric immunosensor. Biosens Bioelectron 91(January):637-643
97. Bourigua $\mathrm{S}$ et al (2010) Impedimetric immunosensor based on SWCNT-COOH modified gold microelectrodes for label-free detection of deep venous thrombosis biomarker. Biosens Bioelectron 26(4):1278-1282

98. Asav E, Sezgintürk MK (2014) A novel impedimetric disposable immunosensor for rapid detection of a potential cancer biomarker. Int J Biol Macromol 66:273-280

99. Elshafey R, Tavares AC, Siaj M, Zourob M (2013) Electrochemical impedance immunosensor based on gold nanoparticles-protein $\mathrm{G}$ for the detection of cancer marker epidermal growth factor receptor in human plasma and brain tissue. Biosens Bioelectron 50:143-149

100. Dall'era MA et al (2008) Active surveillance for early-stage prostate cancer: review of the current literature. Cancer 112(8):1650-1659

101. Gutiérrez-Zúñiga GG, Hernández-López JL (2016) Sensitivity improvement of a sandwich-type ELISA immunosensor for the detection of different prostate-specific antigen isoforms in human serum using electrochemical impedance spectroscopy and an ordered and hierarchically organized interfacial supramolecular architecture. Anal Chim Acta 902:97-106

102. Liu S, Han M (2005) Synthesis, functionalization, and bioconjugation of monodisperse, silica-coated gold nanoparticles: robust bioprobes. Adv Funct Mater 15(6):961-967

103. Petryayeva E, Algar WR, Medintz IL (2013) Quantum dots in bioanalysis: a review of applications across various platforms for fluorescence spectroscopy and imaging. Appl Spectrosc 67(3):215-252

104. Johari-Ahar $M$ et al (2015) An ultra-sensitive impedimetric immunosensor for detection of the serum oncomarker CA-125 in ovarian cancer patients. Nanoscale 7(8):3768-3779

105. Elshafey R, Tlili C, Abulrob A, Tavares AC, Zourob M (2013) Label-free impedimetric immunosensor for ultrasensitive detection of cancer marker Murine double minute 2 in brain tissue. Biosens Bioelectron 39(1):220-225

106. Lima D et al (2019) Label-free impedimetric immunosensor based on arginine-functionalized gold nanoparticles for detection of DHEAS, a biomarker of pediatric adrenocortical carcinoma. Biosens Bioelectron 133(February):86-93

107. Cui $\mathrm{H}$ et al (2013) An AC electrokinetic impedance immunosensor for rapid detection of tuberculosis. Analyst 138(23):7188-7196

108. Montrose A, Cargou S, Nepveu F, Manczak R, Gué AM, Reybier K (2013) Impedimetric immunosensor for the detection of circulating pro-inflammatory monocytes as infection markers. Biosens Bioelectron 49:305-311

109. Steeland S, Vandenbroucke RE, Libert C (2016) Nanobodies as therapeutics: big opportunities for small antibodies. Drug Discov Today 21(7):1076-1113

110. Li G et al (2016) Generation of small single domain nanobody binders for sensitive detection of testosterone by electrochemical impedance spectroscopy. ACS Appl Mater Interfaces 8(22):13830-13839

111. Goode J, Dillon G, Millner PA (2016) The development and optimisation of nanobody based electrochemical immunosensors for IgG. Sens Actuators B Chem 234:478-484

112. Zhurauski $P$ et al (2018) Sensitive and selective Affimer-functionalised interdigitated electrode-based capacitive biosensor for Her4 protein tumour biomarker detection. Biosens Bioelectron 108:1-8

Publisher's Note Springer Nature remains neutral with regard to jurisdictional claims in published maps and institutional affiliations. 